\title{
Bioethanol production from coconuts and cactus pretreated by autohydrolysis
}

\author{
Fabiano Avelino Gonçalves ${ }^{\mathrm{a}, \mathrm{b}}$, Héctor A. Ruiz ${ }^{\mathrm{b}, \mathrm{c}}$, Everaldo Silvino dos Santos ${ }^{\mathrm{a}}$, \\ José A. Teixeira ${ }^{\mathrm{b}}$, Gorete Ribeiro de Macedo ${ }^{\mathrm{a}, *}$ \\ a Laboratory of Biochemical Engineering, Chemical Engineering Department, Federal University of Rio Grande do Norte, 59078-970 Natal, Brazil \\ ${ }^{b}$ CEB - Centre of Biological Engineering, University of Minho, Campus de Gualtar, 4710-057 Braga, Portugal \\ c Biorefinery Group, Food Research Department, School of Chemistry, Autonomous University of Coahuila, Blvd. V. Carranza e Ing. José Cárdenas Valdés, \\ 25280 Saltillo, Coahuila, Mexico
}

\section{A R T I C L E I N F O}

\section{Article history:}

Received 11 February 2015

Received in revised form 11 June 2015

Accepted 15 June 2015

\section{Keywords:}

Autohydrolysis

Enzymatic process

Cactus

Coconuts

Cellulosic ethanol

Presaccharification

\begin{abstract}
A B S T R A C T
The use of coconut fiber mature, green coconut shell, mature coconut shell and cactus is an important alternative as substrates for bioethanol production, since these lignocellulosic materials (LCMs) are abundant in Brazil, mainly in the Northeast Region. The first objective of this work was to evaluate the autohydrolysis pretreatment (AP) on these LCMs and the susceptibility of the treated materials to enzymatic hydrolysis (EH). The second part of the work deals with the application of semi-simultaneous saccharification and fermentation (SSSF) and simultaneous saccharification and fermentation (SSF) using Zymomonas mobilis, Pichia stipitis, Saccharomyces cerevisiae and as substrate the green coconut shell (selected according to the results obtained in the first part of the work). The LCMs after AP using the highest severity factor (4.64) showed changes in the chemical composition in comparison to the untreated LCMs: between the LCMs the cellulose increase was $48.55 \%$, the hemicellulose decrease was $76.77 \%$ and an increase of $62.26 \%$ was observed for lignin. The green coconut shell was characterized by SEM, X-ray and FTIR after AP and its EH conversion into glucose was 92.52\%. The best results on ethanol yield (90.09\%) and ethanol productivity $(0.21 \mathrm{~g} /(\mathrm{L} \mathrm{h}))$ from green coconut shell were obtained by $S$. cerevisiae using SSSF. Overall, an efficient process for the bioethanol production from green coconut shell was developed.
\end{abstract}

(c) 2015 Elsevier B.V. All rights reserved.

\section{Introduction}

In search to mitigate climate change and fossil fuel dependence of some countries, arise as an alternative biofuel production, especially ethanol produced from sugarcane sucrose and cornstarch. However, both processes have economical and environmental limitations for its productive expansion. Thus, a promising option to increase the ethanol supply is the use of lignocellulosic materials (LCMs) as substrate, which are initially converted in fermentable sugars from pretreatment and EH processes and subsequent fermentation. Attempts to produce ethanol from LCMs are old and originated in Germany and Russia over 80 years ago from the saccharification of LCM by acid hydrolysis (Bastos, 2007).

The LCMs used for ethanol production should be from forests (extracted from vegetable or cultivated), agroindustrial and urban wastes, vegetables grown in inhospitable environments and

\footnotetext{
* Corresponding author.

E-mail address: gomacedo@eq.ufrn.br (G.R. de Macedo).
}

photosynthetic aquatic biomass (Gonçalves et al., 2014). In this context, this work uses agroindustrial waste (coconut fiber mature, green coconut shell and mature coconut shell), urban waste (green coconut shell) and vegetable cultivated in inhospitable environments (cactus) aiming at the bioethanol production. According to FAO (2012), the global production of coconut in 2009 was approximately 55 million tons, mainly in the Philippines, Indonesia and India. The fourth largest producer of coconut is Brazil (IBGE, 2012). Besides, in 2009, the production of cactus in Brazil was 60,000 tons (IBGE, 2012).

The recalcitrance of these LCMs demands a pretreatment to facilitate enzymatic action (Romaní et al., 2010). Several methods for vegetable biomass pretreatment have been studied, e.g., biological, physical, chemical or its combination. The autohydrolysis pretreatment (also called liquid hot water or hydrothermal processing - AP) was initially used by Bobleter et al. (1976) to increase susceptibility to EH of LCMs. Normally, the advantages in the use of AP are the simple operation, absence of corrosion in the equipment, unnecessary use of chemical solvent, except water, addition to low operating costs (Cybulska et al., 2010; Romaní 
et al., 2010). In this way, the AP has important features in the preservation of the environment (Garrote et al., 2003).

The AP is carried out by the heating the aqueous suspension in the presence of the LCMs and resulting in the depolymerization and solubilization of the hemicellulose in the liquid phase (oligosaccharides and monosaccharides) (Romaní et al., 2012; Ruiz et al., 2013), as well as products of sugar degradation (furfural and hydroxymethylfurfural - HMF) and acetic acid (Ruiz et al., 2013). Surface area and porosity of LCM increases (Cybulska et al., 2010) and re-location of the lignin on the surface of the LCMs (Ruiz et al., 2013) occurs that, together with an increase in the fraction of the cellulose in the pretreated LCMs, contributes to the improvement of the susceptibility of these solids to EH (Ruiz et al., 2013). The solubilization of hemicellulose by AP may be considered as the first stage in the implementation of the biorefinery concept (Romaní et al., 2011) that makes possible the selective separation of the most important components contained in the LCMs (hemicellulose, cellulose and lignin) including the recovery of lignin after distillation of the fermented broth.

This biorefinery concept consists of an industrial installation that unites equipment and conversion processes to produce power, fuels and other chemicals derived of LCMs (NREL, 2012), use the resources in a sustainable way, without producing waste and other environmental pollutants, based on the association of cleaner processes (Luo et al., 2010). The biorefinery based on lignocellulose is a promising strategy to the implementation of this concept (Uihlein and Schebek, 2009).

Moreover, there are different fermentative strategies for bioethanol production (Shen and Agblevor, 2011). Lately, the separate hydrolysis and fermentation (SHF) have shown to have several disadvantages relative the yield and volumetric productivity of ethanol compared with SSF. Furthermore, the SSF has less processing time, enzymatic inhibition and equipment costs (Shen and Agblevor, 2010). However, for an efficient SSF is necessary approaches the optimal temperature of enzymatic action and the growth of microorganism (De Souza et al., 2012). The fermentative strategy of SSSF consists an interesting alternative that has a small presaccharification period prior to the SSF and shows higher ethanol productivity, yield and concentration compared to SHF and SSF strategies (Shen and Agblevor, 2011).

The objective of this work was to study the AP on cactus, coconut fiber mature, green coconut shell and mature coconut shell followed by EH as a suitable LCMs material for bioethanol production. Moreover, SSF and SSSF strategies for bioethanol production utilizing Pichia stipitis, Saccharomyces cerevisiae and Zymomonas mobilis were developed.

\section{Materials and methods}

\subsection{Raw material, chemical and physical agents in the chemical characterization}

The LCMs used in this work were the cactus, coconut fiber mature, green coconut shell and mature coconut shell derivatives of the urban locations and agroindustries in Brazil (Northeast Region).

The chemical characterization was carried out with $0.3 \mathrm{~g}$ from LCMs and $5 \mathrm{~mL}$ of sulphuric acid (concentration of $72 \%(\mathrm{w} / \mathrm{w})$ ) during $1 \mathrm{~h}$. The post-hydrolysis using 4\% sulphuric acid and adding water (until $148.67 \mathrm{~g}$ ) at $121^{\circ} \mathrm{C}$ for $1 \mathrm{~h}$. Before analyzing in high performance liquid chromatography (HPLC), the LCMs solids residues derivatives of post-hydrolysis process were recovered by the filtration and regarded as Klason lignin, based on standard test methods (T-249 and T-264) of the Technical Association of the Pulp and Paper Industry (TAPPI) (www.tappi.org). Monosaccharides, acetic acid, furfural and HMF contained in the hydrolysates were
Table 1

Autohydrolysis pretreatment of LCMs. (A) Operational conditions; (B) severity factor.

\begin{tabular}{|c|c|c|c|c|}
\hline \multicolumn{5}{|l|}{ A } \\
\hline \multirow[t]{4}{*}{ Assay } & \multicolumn{4}{|c|}{ Operational conditions } \\
\hline & \multicolumn{2}{|c|}{ Real value } & \multicolumn{2}{|c|}{ Normalized variables $^{\mathrm{a}}$} \\
\hline & $T\left({ }^{\circ} \mathrm{C}\right)$ & $t(\min )$ & $T\left({ }^{\circ} \mathrm{C}\right)$ & $t(\min )$ \\
\hline & $X_{1}$ & $X_{2}$ & $X_{1}$ & $X_{2}$ \\
\hline 1 & 160 & 10 & -1 & -1 \\
\hline 2 & 160 & 50 & -1 & 1 \\
\hline 3 & 160 & 30 & -1 & 0 \\
\hline 4 & 200 & 10 & 1 & -1 \\
\hline 5 & 200 & 50 & 1 & 1 \\
\hline 6 & 200 & 30 & 1 & 0 \\
\hline 7 & 180 & 10 & 0 & -1 \\
\hline 8 & 180 & 50 & 0 & 1 \\
\hline 9 & 180 & 30 & 0 & 0 \\
\hline 10 & 180 & 30 & 0 & 0 \\
\hline
\end{tabular}

B Severity factor $\left(R_{0}\right)$

\begin{tabular}{llll}
\hline$T\left({ }^{\circ} \mathrm{C}\right) / t(\mathrm{~min})$ & 10 & 30 & 50 \\
\hline 160 & 2.76 & 3.24 & 3.46 \\
180 & 3.35 & 3.83 & 4.05 \\
200 & 3.94 & 4.42 & 4.64
\end{tabular}

Note: the mathematical model (Eq. (1)) corresponding to the severity parameter $\log R_{0}$ is $R_{0}=\int_{0}^{t} \exp \left(\frac{T-100}{14.75}\right) d t$.

a $X_{1}$ : temperature, $X_{2}$ : time.

determined by the HPLC, with the purpose of content estimate of the acetyl groups, arabinan, cellulose and xylan of samples. Compositions of LCMs were based in the protocol analysis of National Renewable Energy Laboratory (NREL) (Sluiter et al., 2008) and its subsequent amendments. Residual ash content was estimated from $2 \mathrm{~g}$ sample maintained at $550^{\circ} \mathrm{C}$ by $5 \mathrm{~h}$ and weighed to measure the residual ash content (Sluiter et al., 2008). Moisture was determined from $2 \mathrm{~g}$ sample maintained at $105^{\circ} \mathrm{C}$ by $24 \mathrm{~h}$ and weighed to calculate the dry weight (Sluiter et al., 2008).

\subsection{Pretreatment stage}

\subsubsection{Preparation of lignocellulosic materials before of the pretreatment}

The LCMs were initially washed with the purpose of withdrawing the residual compounds existing. Afterwards of five washes utilizing water $\left(70^{\circ} \mathrm{C}\right)$, the LCMs were dried in an oven with air circulation during $24 \mathrm{~h}$ at $40^{\circ} \mathrm{C}$. After this procedure, the LCMs were milled to standardize a particle size of $0.3 \mathrm{~mm}$ ( 48 mesh) (Gonçalves et al., 2014).

\subsubsection{Autohydrolysis pretreatment (AP)}

The LCMs and water were mixed to obtain a ratio $1: 10$ solid/liquid $(\mathrm{v} / \mathrm{w})$, the conditions and severity of pretreatment are shown in Table $1 \mathrm{~A}$ and $\mathrm{B}$. The stainless steel cylinders reactors with total volume of $50 \mathrm{~mL}$ were utilized in the experiments. These reactors were closed and then immersed in oil bath (Julabo, Germany) equipped with a PID temperature control, pre-heated to the desired reaction temperature, based on Table 1 . After the end of the desired reaction time established in Table 1 , the reactors were removed from the oil bath and submerged in an ice-water bath during $5 \mathrm{~min}$. The solid phase and liquid (liquor) were separated by vacuum filtration (Ruiz et al., 2012), both being characterized according to the methods presented in Sections 2.3 and 2.4. The effects of the temperature and time on pretreated LCMs were analyzed according to severity parameter of the $\log R_{0}$ (Overend and 
Chornet, 1987) (Eq. (1)). The experiments were performed in duplicate (Table $1 \mathrm{~A})$.

The mathematical model (Eq. (1)) corresponding to the severity parameter $\log R_{0}$ is:

$R_{0}=\int_{0}^{t} \exp \left(\frac{T-100}{14.75}\right) d t$

where $t$ : reaction time $(\mathrm{min}) ; \mathrm{T}$ : temperature $\left({ }^{\circ} \mathrm{C}\right) ; 100$ : reference temperature; 14.74 : empirical parameter related to the activation energy (pseudo first order kinetics).

The residence times during heating at constant temperature and the constant set temperatures allowed the calculate of $\log R_{0}$ values. Both the heating and cooling were not considerate.

\subsubsection{The experimental design and the statistical analysis}

For determining the dependent variable: cellulose (cellulose, \%); independent variables: temperature $\left(X_{1},{ }^{\circ} \mathrm{C}\right)$ and time $\left(X_{2}, \mathrm{~min}\right)$ in LCMs pretreated by AP, a $2^{2}$ with central composite experimental design using 3 factors, enabling the production of second order polynomials in the independent variables. Besides using the identification of the variables related to statistical significance.

The mathematical model related to the experimental design is shown in Eq. (2) as:

$Y_{i}=\beta_{0}+\beta_{1} X_{1}+\beta_{2} X_{2}+\beta_{11} X_{1}^{2}+\beta_{22} X_{2}^{2}+\beta_{12} X_{1} X_{2}$

where $Y_{i}$ : response function; $X_{1}, X_{2}$ : values in relation to the independent variables; $\beta_{0}$ : coefficient relating to the interception of the plane with the axis of response; $\beta_{1}, \beta_{2}$ : linear coefficients estimated by the method of least squares; $\beta_{11}, \beta_{22}$ : coefficient of the quadratic variables; $\beta_{12}$ : coefficient of the relationship among the independent variables.

The coefficient of determination $R^{2}$ allowed to evaluate the quality of the fit in the polynomial model equation. The Fisher's F-test allowed to evaluate the statistical significance from analysis of variance (ANOVA) using confidence level of 95\%. Also, the effects of the independent variables and the interaction effects correspondent were determined. The Pareto charts regarding the effects and interactions were created from the ANOVA results. The software utilized in the data analysis was Statistica 7.0.

\subsection{Characterization of the solids after autohydrolysis pretreatment}

\subsubsection{Chemical composition of LCMs}

The LCMs were characterized as described above (see Section 2.1).

\subsubsection{Crystallinity and $X$-ray diffraction analysis}

The LCMs untreated and pretreated were analyzed in the Xray diffractometry (Bruker D8 Discover, USA) to determine the crystalline of the cellulose. The operational conditions were the radiation from $\mathrm{Cu} \mathrm{K} \alpha, 40 \mathrm{kV}$ of voltage, $40 \mathrm{~mA}$ of electrical current and a rate of 2 degrees per min using continuous scanning angle $2 \theta$ from 4 to 70 . Eq. (3) was used for defining the crystallinity index (CI) (Segal et al., 1959).

$C I=\frac{I_{002}-I_{a m}}{I_{0} 02} .100$

where $I_{002}$ : maximum intensity $\left(2 \theta, 22.6^{\circ}\right)$ for lattice diffraction (002); $I_{a m}$ : amorphous diffraction intensity $\left(2 \theta, 18.7^{\circ}\right)$.

\subsubsection{Scanning electron microscopy (SEM) of LCMs}

The surfaces of LCMs untreated and pretreated were analyzed in a Nova NanoSEM 200. The samples were initially covered by a gold layer using a cathodic sputtering process, a voltage of $15 \mathrm{kV}$ and afterwards visualized by SEM.

\subsection{Characterization of the liquid phase after autohydrolysis pretreatment}

The liquor phase was separated by filtration after the autohydrolysis pretreatment. The liquors were analyzed by HPLC (see Section 2.8). A second sample with $20 \mathrm{~mL}$ of this liquor was utilized for quantitative the pos-thydrolysis. Thus, the sample was subjected to a solution of $4 \%$ sulphuric acid at $121^{\circ} \mathrm{C}$ for $1 \mathrm{~h}$, and then the HPLC analysis (Garrote et al., 2002). This posthydrolysis step of the liquor resulting of autohydrolysis pretreatment consists in quantify the oligosaccharides from acid hydrolysis (sulphuric acid), because autohydrolysis pretreatment possesses low hydrolysis these oligosaccharides.

Eqs. (4)-(13) were used to determine the following components: (1) the proportion of furfural $\left(F_{C}\right)$, xylooligosaccharides $\left(X O_{C}\right)$ and xylose $\left(X y l_{C}\right)$ from of xylan; (2) the proportion of arabinose $\left(\mathrm{Ara}_{\mathrm{C}}\right)$ and arabino-oligosaccharides $\left(\mathrm{ArO}_{\mathrm{C}}\right)$ from of arabinan; (3) the proportion of acetic acid $\left(\mathrm{Acl}_{C}\right)$ and acetyl groups linked to oligosaccharides $\left(\mathrm{AcO}_{\mathrm{C}}\right)$ from of acetyl groups; (4) the proportion of $\mathrm{HMF}\left(H M F_{C}\right)$, glucose $\left(G u_{C}\right)$ and glucooligosaccharides $\left(G O_{C}\right)$ from of cellulose (Garrote et al., 2002).

$$
\begin{aligned}
& X O_{C}=\frac{132}{150} \cdot \frac{X O}{X y l_{F S}} \cdot \frac{W_{L}}{W_{F S}} \cdot 10 \\
& X y l_{C}=\frac{132}{150} \cdot \frac{X y l}{X y l_{F S}} \cdot \frac{W_{L}}{W_{F S}} \cdot 10 \\
& A r O_{C}=\frac{132}{150} \cdot \frac{A r O}{A r a_{F S}} \cdot \frac{W_{L}}{W_{F S}} \cdot 10 \\
& \operatorname{Ara}_{C}=\frac{132}{150} \cdot \frac{A r a}{A r a_{F S}} \cdot \frac{W_{L}}{W_{F S}} \cdot 10 \\
& F_{C}=\frac{132}{96} \cdot \frac{F}{X y l_{F S}} \cdot \frac{W_{L}}{W_{F S}} \cdot 10 \\
& A_{C} O_{C}=\frac{43}{60} \cdot \frac{A_{C} O S}{A_{C} l_{F S}} \cdot \frac{W_{L}}{W_{F S}} \cdot 10 \\
& A_{C} l_{C}=\frac{43}{60} \cdot \frac{A_{C} l}{A_{C} l_{F S}} \cdot \frac{W_{L}}{W_{F S}} \cdot 10 \\
& G O_{C}=\frac{162}{180} \cdot \frac{G O}{G l u_{F S}} \cdot \frac{W_{L}}{W_{F S}} \cdot 10 \\
& G l u_{C}=\frac{162}{180} \cdot \frac{G l u}{G l u_{F S}} \cdot \frac{W_{L}}{W_{F S}} \cdot 10 \\
& H M F_{C}=\frac{162}{126} \cdot \frac{H M F}{G l u_{F S}} \cdot \frac{W_{L}}{W_{F S}} \cdot 10
\end{aligned}
$$

where $\mathrm{XO}_{C}$ : xylooligosaccharides; $\mathrm{Xyl}_{C}$ : xylose; $F_{C}$ : furfural; $\mathrm{ArO}_{C}$ : arabino-oligosaccharides; $\mathrm{Ara}_{C}$ : arabinose; $\mathrm{AcO}_{C}$ : acetyl groups linked to oligosaccharides; $A_{C} L_{C}$ : acetic acid; $G O_{C}$ : glucooligosaccharides; $G u_{C}$ : glucose; $H M F_{C}$ : hydroxymethylfurfural; $W_{L}$ : initial weight of liquor; $W_{F S}$ : final weight of the liquor submitted to posthydrolysis step; $c$ : converted ${ }_{L}:$ initial; ${ }_{F S}$ : final.

The following ratios are related to the stoichiometric factors of the conversion: cellulose into HMF is $162 / 126$; cellulose into glucose is 162/180; acetyl groups into acid acetic is $43 / 60$; arabinan into arabinose is $132 / 150$; xylan into furfural is $132 / 96$ and xylan into xylose is $132 / 150$ (Garrote et al., 2002).

\subsection{Enzymes}

Enzyme solutions: Cellic CTec 2 containing cellulases, hemicellulases and $\beta$-glucosidase; HTec 2 containing hemicellulases (endoxylanase) from Novozymes A/S (Bagsvaerd, Denmark). 
In the Cellic CTec 2 , the total cellulase activity and $\beta$-glucosidase activity were analyzed using the standard methodology of Mandels et al. (1976) and Ghose (1987), respectively. In the HTec 2, the xylanase activity was determined using the standard methodology of Ghose (1987). The Cellic CTec 2 kit shown the initial enzyme activities from $\beta$-glucosidase and cellulase of $269 \mathrm{CBU} / \mathrm{mL}$ and 126 FPU/mL, respectively, and Cellic HTec 2 kit shown $1654 \mathrm{IU} / \mathrm{mL}$ of endoxylase.

\subsection{Enzymatic hydrolysis (EH)}

\subsubsection{Hydrolysis yield}

The pretreated LCMs were utilized as substrate in the EH step. The EH were carried out using $4 \%(\mathrm{w} / \mathrm{v})$ solutions of pretreated LCM in Erlenmeyer flasks with a volume of $48 \mathrm{~mL}$ at $50^{\circ} \mathrm{C}$, using the enzymatic kit of Cellic CTec 2 and HTec 2, an enzyme loading of $130 \mathrm{IU}, 75 \mathrm{CBU}$ and $30 \mathrm{FPU}$ per gram of pretreated LCM, respectively, and $0.02 \%(\mathrm{w} / \mathrm{v})$ of sodium azide inserted into $50 \mathrm{mM}$ sodium citrate buffer. Submitted the agitation of $150 \mathrm{rpm}$ and the samples were withdrawals at the $0 \mathrm{~h}, 6 \mathrm{~h}$ and $12 \mathrm{~h}$, after in intervals of $12 \mathrm{~h}$ until reach $96 \mathrm{~h}$ of process (Dowe and McMillan, 2001; Santos et al., 2010). The samples were analyzed by HPLC (see Section 2.8). All procedures were performed in duplicate. The Eq. (14) was used for calculate the yield EH (Dowe and McMillan, 2001).

Hydrolysis yield $(\%)=\frac{\text { [glucose }]+1.053 \text { [cellobiose }]}{1.111 f *[\text { biomass }]} \times 100$

where glucose: glucose concentration $(\mathrm{g} / \mathrm{L})$; cellobiose: cellobiose concentration $(\mathrm{g} / \mathrm{L})$; biomass: dry concentration of the biomass initial in the $\mathrm{EH}(\mathrm{g} / \mathrm{L}) ; f$ : cellulose fraction in the dry biomass $(\mathrm{g} / \mathrm{g})$; 1.111: conversion factor of the cellulose into glucose equivalent; 1.053: conversion factor of the cellobiose into glucose equivalent.

\subsubsection{Statistical analysis of the enzymatic hydrolysis}

The single-factor from ANOVA was used in the statistical analysis of the EH and the statistical significance was with a confidence level of $95 \%$, using multiple comparison tests. The Statistica 7.0 software was used for the data analyses.

\subsection{Fermentative stage}

\subsubsection{Microorganisms}

The microorganisms' $P$. stipitis, $S$. cerevisiae and $Z$ mobilis were utilized for ethanol production. P. stipitis Y7124, S. cerevisiae PE2 and $Z$. mobilis B14023 strains were obtained from the microbiological collection of the Centre of Biological Engineering (CEB) at the University of Minho (UMINHO). The microorganisms were stored in Eppendorf with glycerol at $-80^{\circ} \mathrm{C}$ and lyophilized, used as a material stock.

\subsubsection{Preparation of inoculum}

The $S$. cerevisiae and P. stipitis were kept in the Petri dishes containing as culture medium the potato dextrose agar (PDA) and $Z$. mobilis was kept in ghe Petri dishes containing as culture medium the plate count agar (PCA) at $30^{\circ} \mathrm{C}$ during $24 \mathrm{~h}$.

The microorganisms were cultivated in $250 \mathrm{~mL}$ Erlenmeyer flasks containing: $0.25 \mathrm{~g} / \mathrm{L}$ magnesium sulphate; $0.5 \mathrm{~g} / \mathrm{L}$ potassium phosphate; $10 \mathrm{~g} / \mathrm{L}$ peptone; $1 \mathrm{~g} / \mathrm{L}$ ammonium sulphate; $10 \mathrm{~g} / \mathrm{L}$ yeast extract and $50 \mathrm{~g} / \mathrm{L}$ glucose diluted in $100 \mathrm{~mL}$ of sterile culture medium at $30^{\circ} \mathrm{C}$ and the agitation for S. cerevisiae was $200 \mathrm{rpm}$, $Z$. mobilis was $150 \mathrm{rpm}$ and $P$. stipitis was $250 \mathrm{rpm}$ into an orbital shaker during $12 \mathrm{~h}$ (Santos et al., 2010). The cells in the inoculum were grown till an optical density of 2 for all strains (S. cerevisiae, $P$. stipitis and $Z$. mobilis) measured in a UV-vis spectrophotometer in the wavelength at $600 \mathrm{~nm}$ (De Souza et al., 2012).

\subsubsection{Simultaneous saccharification and fermentation process} (SSF)

The SSF experiments were conducted using the NREL standard procedure (Dowe and McMillan, 2001; Gonçalves et al., 2014). The culture medium was supplemented in accordance with Santos et al. (2010), using P. stipitis, S. cerevisiae and Z. mobilis. The samples were withdrawals at $0 \mathrm{~h}, 6 \mathrm{~h}$ and $12 \mathrm{~h}$, after an interval of $12 \mathrm{~h}$ until it reached $48 \mathrm{~h}$ of process. The samples were analyzed in the HPLC (see Section 2.8). All procedures were performed in duplicate.

\subsubsection{Semi-simultaneous saccharification and fermentation process (SSSF)}

The SSSF included at $12 \mathrm{~h}$ of pre-saccharification $+36 \mathrm{~h}$ of SSF process using pretreated green coconut shell as substrate established by Gonçalves et al. (2014), and P. stipitis, S. cerevisiae and $Z$. mobilis as microorganism. The culture medium was supplemented in accordance with Santos et al. (2010). The samples were withdrawals at $0 \mathrm{~h}, 6 \mathrm{~h}$ and $12 \mathrm{~h}$, after an interval of $12 \mathrm{~h}$ until reach $48 \mathrm{~h}$ of process. The samples were analyzed in the HPLC (see Section 2.8). All procedures were performed in duplicate.

The ethanol yield (Eq. (15)) was calculated for SSF and SSSF. The fermentative processes were estimated with all glucose contained in the pretreated green coconut shell. Furthermore, establishing that $0.51 \mathrm{~g}$ of ethanol from $1 \mathrm{~g}$ of glucose and $0.9 \mathrm{~g}$ of glucose from $1 \mathrm{~g}$ of cellulose (Dowe and McMillan, 2001).

$$
\text { Ethanol yield }(\%)=\frac{[\text { ethanol] }}{[\text { initial glucose or xylose }] \times 0.511} \times 100
$$

where ethanol: final concentration of ethanol $(\mathrm{g} / \mathrm{L})$; initial glucose or xylose: initial concentration of the glucose or xylose $(\mathrm{g} / \mathrm{L}) ; 0.511$ : conversion factor of the glucose or xylose into ethanol.

\subsubsection{Statistical analyzes from SSF and SSSF}

The statistical significance was with a confidence level of $95 \%$ for Fisher F-test (ANOVA) and Student's t-test. The Statistica 7.0 software was used for the data analyses.

\subsection{Analysis of the samples in the high performance liquid chromatography (HPLC)}

The samples of chemical characterization, enzymatic hydrolysis and fermentations were processed (centrifuged, filtered and analyzed by HPLC) to verify the concentration of organic compounds contained. Using Metacarb $87 \mathrm{H}$ column $(300 \mathrm{~mm} \times 7.8 \mathrm{~mm}$ ) (Varian, USA) in a Jasco chromatograph 880-PU pump containing a Jasco 830-IR refraction-index detector and a Jasco AS-2057 Plus auto sampler (Jasco, Japan). The analysis conditions: column at $60^{\circ} \mathrm{C}$; mobile phase of sulphuric acid $(0.005 \mathrm{~mol} / \mathrm{L})$ and flow rate $0.7 \mathrm{~mL} / \mathrm{min}$.

\section{Results and discussion}

\subsection{Composition of the LCMs}

The chemical compositions of the LCMs (untreated and pretreated) are shown in Table 2. The moisture content of the untreated LCMs was $12.60 \%, 5.52 \%, 6.14 \%$ and $8.99 \%$ for cactus, mature coconut shell, coconut fiber mature and green coconut shell, respectively.

The LCMs after AP using the highest severity factor (4.64) showed changes in chemical composition in comparison to the untreated LCMs: for cactus the cellulose content increased 35.39\%, hemicellulose was reduced $76.77 \%$ and lignin increased $37.72 \%$; for green coconut shell, the cellulose increased $23.38 \%$, hemicellulose was reduced $72.27 \%$ and lignin increased $62.26 \%$; for coconut fiber 
Table 2

Composition and yield of pretreated LCMs. (A) Coconut fiber mature; (B) mature coconut shell; (c) green coconut shell; (d) cactus.

\begin{tabular}{|c|c|c|c|c|c|c|}
\hline \multirow[t]{2}{*}{ Ro } & \multirow[t]{2}{*}{ Assay } & \multicolumn{5}{|l|}{ Solid phase (\%) } \\
\hline & & Solid yield & Cellulose & Hemicellulose & Klason lignin & Ash \\
\hline \multicolumn{7}{|l|}{$A$} \\
\hline 0 & Untreated & $100 \pm 0.00$ & $32.18 \pm 0.12$ & $27.81 \pm 0.74$ & $25.02 \pm 0.01$ & $3.31 \pm 0.02$ \\
\hline 2.76 & 1 & $92.74 \pm 0.50$ & $32.54 \pm 0.51$ & $29.15 \pm 0.46$ & $29.29 \pm 0.15$ & $1.59 \pm 0.07$ \\
\hline 3.24 & 2 & $87.76 \pm 0.74$ & $33.86 \pm 0.37$ & $19.48 \pm 0.05$ & $28.20 \pm 0.25$ & $1.60 \pm 0.16$ \\
\hline 3.46 & 3 & $82.96 \pm 1.28$ & $34.59 \pm 0.21$ & $19.46 \pm 0.21$ & $26.66 \pm 0.41$ & $2.60 \pm 0.16$ \\
\hline 3.94 & 4 & $79.86 \pm 0.42$ & $38.35 \pm 0.12$ & $17.41 \pm 0.03$ & $28.12 \pm 0.16$ & $1.98 \pm 0.04$ \\
\hline 4.42 & 5 & $75.47 \pm 0.33$ & $42.55 \pm 1.04$ & $16.67 \pm 0.12$ & $28.68 \pm 0.32$ & $1.67 \pm 0.19$ \\
\hline 4.64 & 6 & $73.94 \pm 0.87$ & $45.23 \pm 1.23$ & $13.86 \pm 0.06$ & $29.80 \pm 0.25$ & $1.35 \pm 0.02$ \\
\hline 3.35 & 7 & $83.76 \pm 1.81$ & $34.52 \pm 0.56$ & $17.80 \pm 0.14$ & $27.01 \pm 0.20$ & $1.18 \pm 0.03$ \\
\hline 4.05 & 8 & $77.44 \pm 1.12$ & $39.98 \pm 0.24$ & $18.73 \pm 0.15$ & $28.37 \pm 0.40$ & $2.53 \pm 0.07$ \\
\hline 3.83 & 9 & $81.89 \pm 0.40$ & $39.53 \pm 0.15$ & $19.46 \pm 0.01$ & $27.44 \pm 0.08$ & $2.02 \pm 0.02$ \\
\hline 3.83 & 10 & $81.78 \pm 0.33$ & $39.85 \pm 0.15$ & $19.82 \pm 0.01$ & $27.48 \pm 0.08$ & $2.46 \pm 0.03$ \\
\hline \multicolumn{7}{|l|}{$B$} \\
\hline 0 & Untreated & $100 \pm 0.00$ & $29.58 \pm 0.50$ & $27.77 \pm 0.79$ & $31.04 \pm 0.10$ & $3.84 \pm 0.08$ \\
\hline 2.76 & 1 & $90.85 \pm 0.09$ & $30.35 \pm 0.17$ & $30.31 \pm 0.02$ & $29.13 \pm 0.47$ & $1.55 \pm 0.11$ \\
\hline 3.24 & 2 & $87.58 \pm 0.19$ & $32.50 \pm 0.52$ & $25.98 \pm 0.88$ & $27.53 \pm 0.49$ & $0.82 \pm 0.20$ \\
\hline 3.46 & 3 & $85.44 \pm 0.44$ & $32.53 \pm 0.27$ & $22.07 \pm 0.24$ & $29.23 \pm 0.40$ & $0.89 \pm 0.05$ \\
\hline 3.94 & 4 & $85.69 \pm 0.59$ & $32.70 \pm 0.59$ & $18.67 \pm 0.49$ & $31.48 \pm 0.22$ & $0.68 \pm 0.06$ \\
\hline 4.42 & 5 & $66.87 \pm 0.20$ & $41.21 \pm 0.11$ & $12.48 \pm 0.15$ & $34.39 \pm 0.09$ & $0.73 \pm 0.03$ \\
\hline 4.64 & 6 & $62.08 \pm 0.02$ & $43.94 \pm 0.53$ & $7.02 \pm 0.05$ & $36.14 \pm 0.05$ & $0.71 \pm 0.07$ \\
\hline 3.35 & 7 & $86.62 \pm 0.31$ & $32.19 \pm 0.52$ & $23.66 \pm 0.17$ & $24.70 \pm 0.20$ & $0.90 \pm 0.10$ \\
\hline 4.05 & 8 & $76.98 \pm 0.47$ & $32.26 \pm 0.41$ & $16.50 \pm 0.53$ & $31.28 \pm 0.03$ & $0.69 \pm 0.10$ \\
\hline 3.83 & 9 & $84.13 \pm 0.15$ & $36.52 \pm 0.18$ & $20.06 \pm 0.13$ & $28.93 \pm 0.13$ & $0.68 \pm 0.11$ \\
\hline 3.83 & 10 & $83.62 \pm 0.84$ & $34.74 \pm 0.90$ & $19.88 \pm 0.09$ & $28.64 \pm 0.41$ & $0.63 \pm 0.13$ \\
\hline \multicolumn{7}{|l|}{$C$} \\
\hline 0 & Untreated & $100 \pm 0.00$ & $33.23 \pm 0.24$ & $29.14 \pm 0.22$ & $25.44 \pm 0.12$ & $2.34 \pm 0.11$ \\
\hline 2.76 & 1 & $89.43 \pm 1.40$ & $30.65 \pm 0.03$ & $23.25 \pm 0.04$ & $32.15 \pm 0.47$ & $1.71 \pm 0.05$ \\
\hline 3.24 & 2 & $86.83 \pm 0.53$ & $32.07 \pm 0.08$ & $21.10 \pm 0.07$ & $30.93 \pm 0.38$ & $1.52 \pm 0.29$ \\
\hline 3.46 & 3 & $84.44 \pm 0.36$ & $33.11 \pm 0.12$ & $19.87 \pm 0.04$ & $34.00 \pm 0.43$ & $1.73 \pm 0.02$ \\
\hline 3.94 & 4 & $80.46 \pm 0.72$ & $34.14 \pm 0.17$ & $18.11 \pm 0.01$ & $31.05 \pm 0.32$ & $0.70 \pm 0.42$ \\
\hline 4.42 & 5 & $74.31 \pm 0.20$ & $38.57 \pm 0.10$ & $14.55 \pm 0.06$ & $37.58 \pm 0.10$ & $1.06 \pm 0.23$ \\
\hline 4.64 & 6 & $68.36 \pm 0.44$ & $41.96 \pm 1.10$ & $8.08 \pm 0.10$ & $41.28 \pm 0.87$ & $1.22 \pm 0.04$ \\
\hline 3.35 & 7 & $88.77 \pm 1.60$ & $30.64 \pm 0.09$ & $20.07 \pm 0.04$ & $30.36 \pm 0.40$ & $1.88 \pm 0.31$ \\
\hline 4.05 & 8 & $77.45 \pm 1.13$ & $35.92 \pm 0.07$ & $16.83 \pm 0.11$ & $33.92 \pm 0.03$ & $0.77 \pm 0.01$ \\
\hline 3.83 & 9 & $82.56 \pm 0.54$ & $33.52 \pm 0.21$ & $18.27 \pm 0.12$ & $34.80 \pm 0.26$ & $1.41 \pm 0.05$ \\
\hline 3.83 & 10 & $82.38 \pm 1.60$ & $34.01 \pm 0.14$ & $18.34 \pm 0.22$ & $34.22 \pm 0.31$ & $1.52 \pm 0.30$ \\
\hline \multicolumn{7}{|l|}{$D$} \\
\hline 0 & Untreated & $100 \pm 0.00$ & $38.12 \pm 0.75$ & $23.50 \pm 0.42$ & $19.51 \pm 0.13$ & $5.64 \pm 0.21$ \\
\hline 2.76 & 1 & $62.34 \pm 0.87$ & $36.67 \pm 0.17$ & $13.22 \pm 0.05$ & $26.73 \pm 0.23$ & $9.37 \pm 0.22$ \\
\hline 3.24 & 2 & $56.69 \pm 0.14$ & $38.94 \pm 0.18$ & $12.89 \pm 0.31$ & $23.87 \pm 0.31$ & $10.62 \pm 0.26$ \\
\hline 3.46 & 3 & $53.19 \pm 0.78$ & $39.95 \pm 0.50$ & $11.87 \pm 0.05$ & $26.90 \pm 0.31$ & $11.47 \pm 0.41$ \\
\hline 3.94 & 4 & $45.17 \pm 0.85$ & $43.14 \pm 0.25$ & $11.01 \pm 0.11$ & $22.12 \pm 0.21$ & $10.45 \pm 0.34$ \\
\hline 4.42 & 5 & $42.95 \pm 1.28$ & $49.82 \pm 0.15$ & $9.88 \pm 0.33$ & $27.11 \pm 0.08$ & $11.37 \pm 0.31$ \\
\hline 4.64 & 6 & $40.36 \pm 0.47$ & $51.61 \pm 0.04$ & $5.46 \pm 0.17$ & $26.87 \pm 0.06$ & $12.25 \pm 0.72$ \\
\hline 3.35 & 7 & $56.18 \pm 0.09$ & $39.59 \pm 0.96$ & $12.00 \pm 0.03$ & $21.34 \pm 0.26$ & $11.30 \pm 0.29$ \\
\hline 4.05 & 8 & $44.74 \pm 0.54$ & $43.65 \pm 0.52$ & $10.92 \pm 0.10$ & $21.85 \pm 0.11$ & $10.34 \pm 0.16$ \\
\hline 3.83 & 9 & $47.15 \pm 0.73$ & $42.65 \pm 1.05$ & $11.74 \pm 0.08$ & $21.89 \pm 0.35$ & $11.56 \pm 0.38$ \\
\hline 3.83 & 10 & $46.85 \pm 0.65$ & $41.83 \pm 0.04$ & $11.45 \pm 0.13$ & $22.22 \pm 0.24$ & $10.89 \pm 0.76$ \\
\hline
\end{tabular}

mature the cellulose increase was $40.55 \%$, the hemicellulose reduction was $50.16 \%$ and lignin increase $19.10 \%$; and for mature coconut shell the cellulose increase was $48.55 \%$, the hemicellulose decrease was $74.71 \%$ and an increase of $16.43 \%$ was observed for lignin. For all pretreated LCMs, a reduction in the hemicellulose content, and increase of cellulose and lignin was observed, these aspects being strategic for the fractionation of LCM, as it allows the hydrolysis of hemicellulose and enriches the material in cellulose and lignin (Ruiz et al., 2013). According to Ballesteros et al. (2002) the hemicellulose degradation in agricultural wastes increases at high temperatures and high residence times, therefore, higher severities factors in operating conditions will provide a higher reduction of hemicellulose, similar to the results obtained in this work. Ruiz et al. (2013) emphasized that the AP causes the re-location of lignin on LCM surface. Thus, the accessibility of enzymes to pretreated LCMs is favored, increasing the hydrolysis of cellulose. Increased porosity and surface area improve EH efficiency (Cybulska et al., 2010).
Pretreated LCMs presented a reduction of solid between $7.26 \%$ and $59.64 \%$, this being correlated with an increase in the severity factor (Table 2). Minimum reductions were observed for cellulose in pretreated mature coconut shell, green coconut shell and coconut fiber mature. Romaní et al. (2010) reported reductions of cellulose mass after the pretreatment in the range of $5.29 \%$ and $19.55 \%$ at $240^{\circ} \mathrm{C}$ and $250^{\circ} \mathrm{C}$, respectively. In addition to Sakaki et al. (2002), they evidence the appearance of the hexoses from cellulose and degradation of oligosaccharides after $230^{\circ} \mathrm{C}$ and the $295^{\circ} \mathrm{C}$ practically all the cellulose was degraded.

\subsection{Liquid phase composition after autohydrolysis pretreatment}

The liquid phase composition after AP carried out at several severities is shown in Table $1 \mathrm{~B}$. In all situations, a reduction in $\mathrm{pH}$ is observed, the lowest one occurring for cactus liquor (Table 3 ). However, the $\mathrm{pH}$ values of the cactus liquors were close to the minimum $\mathrm{pH}$ values encountered for other LCMs, indicating an 
Table 3

Composition of the liquid phase of pretreated LCMs. (A) Coconut fiber mature; (b) mature coconut shell; (c) green coconut shell; (d) cactus.

\begin{tabular}{|c|c|c|c|c|c|c|c|c|c|c|c|c|c|c|}
\hline \multirow[t]{2}{*}{ Ro } & \multirow[t]{2}{*}{ Assay } & \multirow[t]{2}{*}{$\mathrm{pH}$} & \multicolumn{10}{|c|}{ Liquid phase $(\mathrm{g} / \mathrm{L})$} & \multirow[t]{2}{*}{ Total sugar } & \multirow[t]{2}{*}[\mathrm{XO}]{$\%$} \\
\hline & & & Glucose & Xylose & Arabinose & Acetic acid & HMF & Furfural & [GO] & {$[\mathrm{XO}]$} & {$[\mathrm{ArO}]$} & {$[\mathrm{AcO}]$} & & \\
\hline \multicolumn{15}{|l|}{$A$} \\
\hline 2.76 & 1 & 5.85 & 0.13 & 1.16 & 0.11 & 0.25 & 0.01 & 0.10 & 0.39 & 1.80 & 1.22 & 2.79 & 4.81 & 37.42 \\
\hline 3.24 & 2 & 5.00 & 0.12 & 2.17 & 0.30 & 0.12 & 0.02 & 0.16 & 0.44 & 2.44 & 1.51 & 3.47 & 6.98 & 34.96 \\
\hline 3.46 & 3 & 4.70 & 0.13 & 2.22 & 0.67 & 0.37 & 0.04 & 0.18 & 0.43 & 2.68 & 1.99 & 2.84 & 8.12 & 33.00 \\
\hline 3.94 & 4 & 4.80 & 0.12 & 2.52 & 0.39 & 0.32 & 0.03 & 0.18 & 0.45 & 3.79 & 1.42 & 2.84 & 8.69 & 43.61 \\
\hline 4.42 & 5 & 4.30 & 0.13 & 2.46 & 1.09 & 0.60 & 0.09 & 0.32 & 0.58 & 4.89 & 1.53 & 3.00 & 10.68 & 45.79 \\
\hline 4.64 & 6 & 3.95 & 0.12 & 2.77 & 0.86 & 0.86 & 0.06 & 0.76 & 0.56 & 5.01 & 1.21 & 3.10 & 10.53 & 47.58 \\
\hline 3.35 & 7 & 5.30 & 0.13 & 3.17 & 0.36 & 0.27 & 0.01 & 0.18 & 0.43 & 2.70 & 1.31 & 2.78 & 8.10 & 33.33 \\
\hline 4.05 & 8 & 4.40 & 0.13 & 2.35 & 0.11 & 0.50 & 0.07 & 0.24 & 0.55 & 4.26 & 1.85 & 2.98 & 9.25 & 46.05 \\
\hline 3.83 & 9 & 4.55 & 0.12 & 2.25 & 0.69 & 0.37 & 0.04 & 0.18 & 0.49 & 2.65 & 1.85 & 2.86 & 8.05 & 32.92 \\
\hline 3.83 & 10 & 4.60 & 0.13 & 2.28 & 0.97 & 0.43 & 0.06 & 0.20 & 0.51 & 3.18 & 2.17 & 2.94 & 9.24 & 34.42 \\
\hline \multicolumn{15}{|l|}{$B$} \\
\hline 2.76 & 1 & 5.45 & 0.13 & 0.88 & 0.11 & 0.27 & 0.02 & 0.18 & 0.42 & 2.04 & 1.18 & 1.79 & 4.76 & 42.86 \\
\hline 3.24 & 2 & 4.65 & 0.13 & 1.06 & 0.18 & 0.30 & 0.02 & 0.18 & 0.43 & 2.12 & 1.21 & 1.75 & 5.13 & 41.33 \\
\hline 3.46 & 3 & 4.40 & 0.14 & 1.20 & 0.26 & 0.33 & 0.02 & 0.18 & 0.49 & 3.37 & 1.28 & 2.93 & 6.74 & 50.00 \\
\hline 3.94 & 4 & 4.70 & 0.14 & 1.77 & 0.19 & 0.30 & 0.03 & 0.18 & 0.40 & 2.63 & 1.18 & 3.00 & 6.31 & 41.68 \\
\hline 4.42 & 5 & 3.70 & 0.15 & 1.41 & 0.41 & 0.69 & 0.05 & 0.52 & 0.54 & 13.55 & 1.20 & 4.02 & 17.26 & 78.51 \\
\hline 4.64 & 6 & 3.40 & 0.16 & 1.90 & 0.36 & 1.29 & 0.11 & 0.83 & 0.61 & 16.52 & 1.01 & 4.31 & 20.56 & 80.35 \\
\hline 3.35 & 7 & 5.10 & 0.13 & 1.16 & 0.13 & 0.27 & 0.02 & 0.16 & 0.39 & 2.07 & 1.16 & 2.72 & 5.04 & 41.07 \\
\hline 4.05 & 8 & 3.80 & 0.16 & 1.47 & 0.47 & 0.53 & 0.03 & 0.30 & 0.48 & 11.35 & 1.15 & 3.83 & 15.08 & 75.27 \\
\hline 3.83 & 9 & 4.20 & 0.14 & 1.23 & 0.32 & 0.37 & 0.02 & 0.19 & 0.45 & 6.85 & 1.24 & 3.08 & 10.23 & 66.96 \\
\hline 3.83 & 10 & 4.15 & 0.14 & 1.26 & 0.34 & 0.37 & 0.02 & 0.21 & 0.50 & 5.52 & 1.27 & 3.12 & 9.03 & 61.13 \\
\hline \multicolumn{15}{|l|}{$C$} \\
\hline 2.76 & 1 & 5.20 & 0.13 & 1.15 & 0.16 & 0.33 & 0.01 & 0.16 & 0.38 & 1.85 & 1.24 & 2.78 & 4.91 & 37.68 \\
\hline 3.24 & 2 & 4.45 & 0.13 & 1.18 & 0.40 & 0.29 & 0.02 & 0.16 & 0.46 & 2.92 & 1.64 & 2.88 & 6.73 & 43.39 \\
\hline 3.46 & 3 & 4.15 & 0.13 & 1.21 & 0.56 & 0.32 & 0.02 & 0.18 & 0.51 & 4.15 & 2.23 & 3.05 & 8.79 & 47.21 \\
\hline 3.94 & 4 & 4.25 & 0.13 & 1.20 & 0.39 & 0.30 & 0.02 & 0.18 & 0.49 & 5.32 & 1.60 & 2.89 & 9.13 & 58.27 \\
\hline 4.42 & 5 & 3.80 & 0.14 & 1.79 & 0.93 & 0.62 & 0.05 & 0.38 & 0.61 & 11.56 & 1.20 & 3.93 & 16.23 & 71.23 \\
\hline 4.64 & 6 & 3.60 & 0.17 & 3.03 & 0.53 & 1.18 & 0.08 & 0.86 & 0.65 & 12.15 & 1.12 & 3.76 & 17.65 & 68.84 \\
\hline 3.35 & 7 & 4.65 & 0.14 & 1.16 & 0.18 & 0.26 & 0.04 & 0.18 & 0.42 & 3.10 & 1.33 & 2.82 & 6.33 & 48.97 \\
\hline 4.05 & 8 & 3.90 & 0.13 & 1.50 & 0.94 & 0.48 & 0.03 & 0.32 & 0.61 & 8.16 & 1.59 & 3.64 & 12.93 & 63.11 \\
\hline 3.83 & 9 & 4.10 & 0.13 & 1.26 & 0.66 & 0.36 & 0.04 & 0.18 & 0.51 & 5.39 & 1.54 & 3.09 & 9.49 & 56.80 \\
\hline 3.83 & 10 & 4.00 & 0.13 & 1.28 & 0.70 & 0.38 & 0.04 & 0.20 & 0.55 & 5.68 & 1.67 & 3.15 & 10.01 & 56.74 \\
\hline \multicolumn{15}{|l|}{$D$} \\
\hline 2.76 & 1 & 4.10 & 1.73 & 1.72 & 0.16 & 0.27 & 0.06 & 0.22 & 0.22 & 4.52 & 1.96 & 0.28 & 10.31 & 43.84 \\
\hline 3.24 & 2 & 4.00 & 2.67 & 2.84 & 0.53 & 0.35 & 0.08 & 0.24 & 2.49 & 7.56 & 5.12 & 0.94 & 21.21 & 35.64 \\
\hline 3.46 & 3 & 3.90 & 2.52 & 2.77 & 0.87 & 0.58 & 0.23 & 0.22 & 3.30 & 6.89 & 4.51 & 0.90 & 20.86 & 33.03 \\
\hline 3.94 & 4 & 4.10 & 1.74 & 3.01 & 0.45 & 0.34 & 0.21 & 0.20 & 3.52 & 5.14 & 3.33 & 0.62 & 17.19 & 29.90 \\
\hline 4.42 & 5 & 4.00 & 2.43 & 3.75 & 1.09 & 0.78 & 0.44 & 0.70 & 6.57 & 5.06 & 4.15 & 1.30 & 23.05 & 21.95 \\
\hline 4.64 & 6 & 3.80 & 2.72 & 3.71 & 1.29 & 1.06 & 0.54 & 0.94 & 7.23 & 5.47 & 4.32 & 1.20 & 24.74 & 22.11 \\
\hline 3.35 & 7 & 4.10 & 2.79 & 2.83 & 1.10 & 0.31 & 0.21 & 0.38 & 5.07 & 6.20 & 3.62 & 0.50 & 21.61 & 28.69 \\
\hline 4.05 & 8 & 3.90 & 2.87 & 2.87 & 1.05 & 0.67 & 0.41 & 0.38 & 6.34 & 7.15 & 2.82 & 1.53 & 23.10 & 30.95 \\
\hline 3.83 & 9 & 4.00 & 2.36 & 2.78 & 1.07 & 0.51 & 0.24 & 0.24 & 5.84 & 7.26 & 4.01 & 0.96 & 23.32 & 31.13 \\
\hline 3.83 & 10 & 3.90 & 2.16 & 3.05 & 1.11 & 0.52 & 0.27 & 0.26 & 5.92 & 7.75 & 3.60 & 0.87 & 23.59 & 32.85 \\
\hline
\end{tabular}

Note: GO: glucooligosaccharides; XO: xylooligosaccharides; ArO: arabino-oligosaccharides; AcO: acetyl groups linked to oligosaccharides.

increased sensitivity of cactus to the different severities used in autohydrolysis pretreatment. Pretreated LCMs present a correlation between the reduction of the $\mathrm{pH}$ and the increase in the concentration of acetic acid, furfural, HMF, arabinose, xylose, GO, $\mathrm{XO}, \mathrm{AcO}$ and $\mathrm{ArO}$ in the liquor. Cybulska et al. (2010) studied the importance of monitoring and controlling the $\mathrm{pH}$ to maximize the solubilization of hemicellulosic fraction. Cara et al. (2007) reported a decreased $\mathrm{pH}$ for AP materials correlated with an increased concentration of the degradation product of hemicellulose (furfural); similar results were obtained in this work (Table 3 ).

The highest concentrations of acetic acid, furfural, HMF, arabinose, xylose, $\mathrm{XO}$ and $\mathrm{AcO}$ were observed for green coconut shell, coconut fiber mature and mature coconut shell. Furthermore, oligosaccharides were obtained at higher concentrations than monosaccharides, these results also are being correlated with $\mathrm{pH}$ reduction and with the severity factor. Low amounts of cellulose or hemicellulose were degraded into GO in coconut fiber mature, mature coconut shell and green coconut shell. Similar results were obtained for AP rye straw (Gullón et al., 2010). Cactus presented higher concentrations of monomeric sugars, acetic acid, HMF, furfural, GO and ArO. These values are related to an increase in the severity factor and the highest concentrations obtained in the cactus liquors indicate a higher sensitivity of cactus to AP.

Monosaccharides and oligosaccharides present in the liquor can be used in others biotechnological processes (Ruiz et al., 2013). The Moure et al. (2006) reported the possibility of using these carbohydrates in food and pharmaceutical industries, and on the production of cellulosic ethanol and xylitol.

\subsection{Experimental design and statistical analysis of pretreated LCMs}

The experimental design was conducted to determine variables that affect the pretreatment of LCMs and influence the cellulose content contained in the pretreated material. The conditions used in the experimental design were temperature $\left(160,180\right.$ and $\left.200^{\circ} \mathrm{C}\right)$ and time (10, 30 and $50 \mathrm{~min})$.

The ANOVA and multiple regression analysis of the experimental data were carrie out from mathematical model fitting. Models describing the AP materials cellulosic content the temperature $\left(X_{1}\right)$ and time $\left(X_{2}\right)$ as a function and using normalized values (Table $1 \mathrm{~A}$ ) are described by Eqs. (16)-(19) for coconut fiber mature, mature 
A

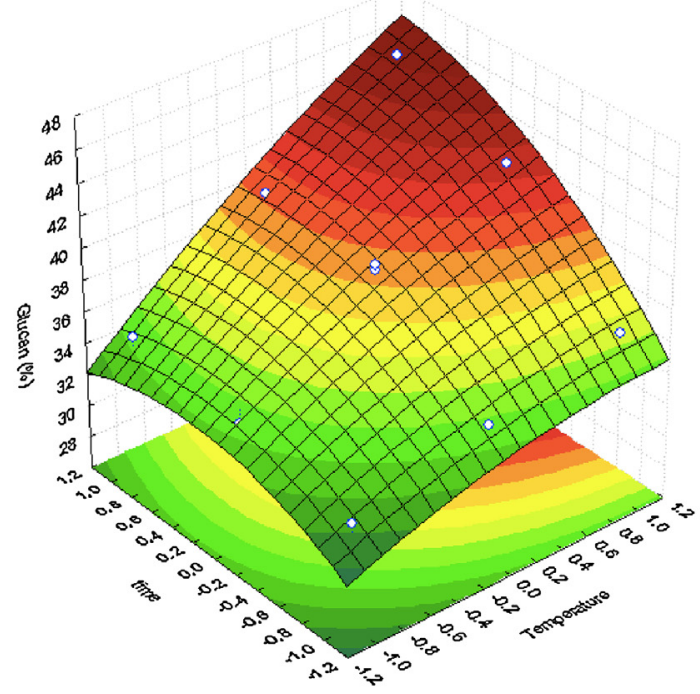

C

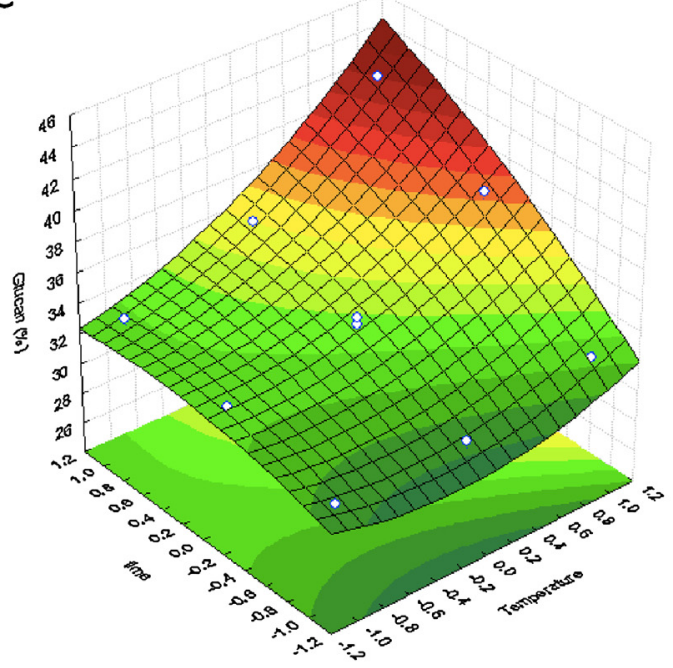

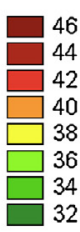

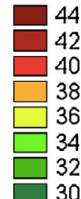

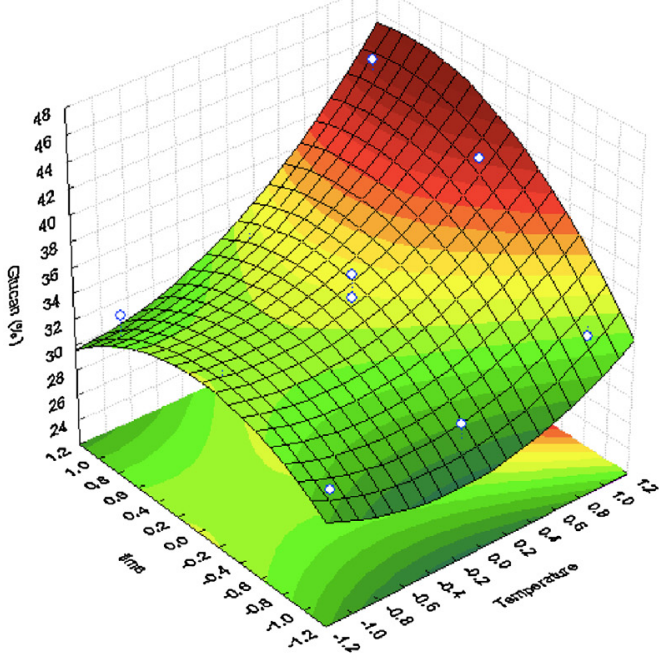

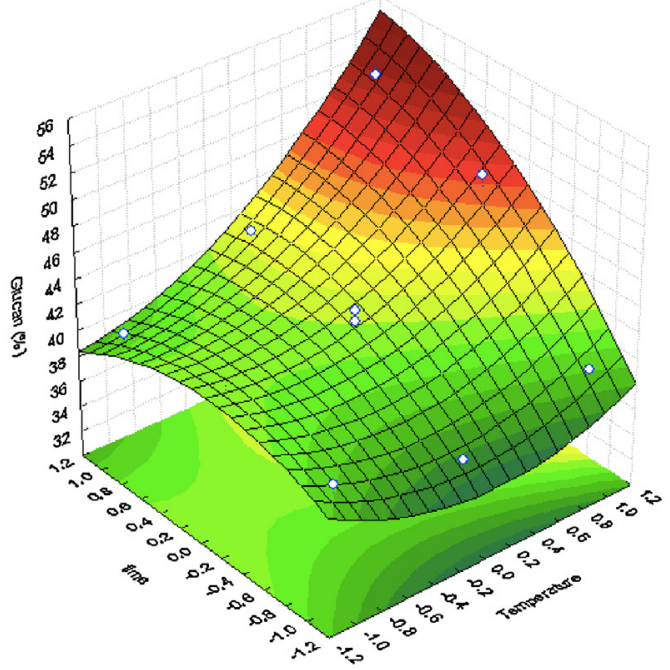

D

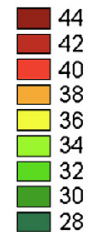

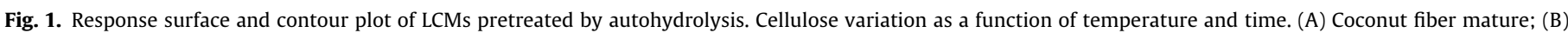
mature coconut shell; (C) green coconut shell; (D) cactus.

coconut shell, green coconut shell and cactus, respectively,

Coconut fibre mature : \% Cellulose $=39.28+3.85 *$ Temperature

$-0.67 *$ Temperature $^{2}+2.73 *$ time $-1.63 *$ time $^{2}+1.70$

$*$ Temperature $*$ time $\quad\left(R^{2}=0.9878 ; R_{\text {adj }}^{2}=0.9725\right)$

Mature coconut shell : \% Cellulose $=34.99+3.74 *$ Temperature

$+2.5 *$ Temperature $^{2}+2.51 *$ time $-2.93 *$ time $^{2}+2.26$

$*$ Temperature $*$ time $\quad\left(R^{2}=0.9251 ; R_{a d j}^{2}=0.9315\right)$

Green coconut shell : \% Cellulose $=33.85+2.80 *$ Temperature

$+1.35 *$ Temperature $^{2}+2.92 *$ time $-0.68 *$ time $^{2}+1.83$

$*$ Temperature $*$ time $\quad\left(R^{2}=0.9914 ; R_{a d j}^{2}=0.9808\right)$
Cactus : \% Cellulose $=42.24+3.23 *$ Temperature

$$
\begin{aligned}
& +2.37 * \text { Temperature }^{2}+3.33 * \text { time }-2.09 * \text { time }^{2} \\
& +3.08 * \text { Temperature } * \text { time } \quad\left(R^{2}=0.9834 ; R_{a d j}^{2}=0.9627\right)
\end{aligned}
$$

The response surfaces were designed as three dimensional plots of the second order polynomial models (Eqs. (16)-(19), as a function of the two most strongly influencing variables. Cellulose variation was represented in function of the temperature and time (Fig. 1) and it was demonstrated that the increase in cellulose is correlated with the increase in the AP of the temperature and time.

The ANOVA results (see Eqs. (16)-(19)) showed that the second order polynomial models represents properly the responses in the cellulose variation. Obtained coefficients of determination $R^{2}$ show that $98.8 \%, 92.5 \%, 99.4 \%$ and $98.3 \%$ of the variability of response may be described by the model. The values are in conform to adjusted coefficients of determination $-R_{a d j}{ }^{2}=0.973,0.932,0.980$ and 0.963 , respectively. 
A
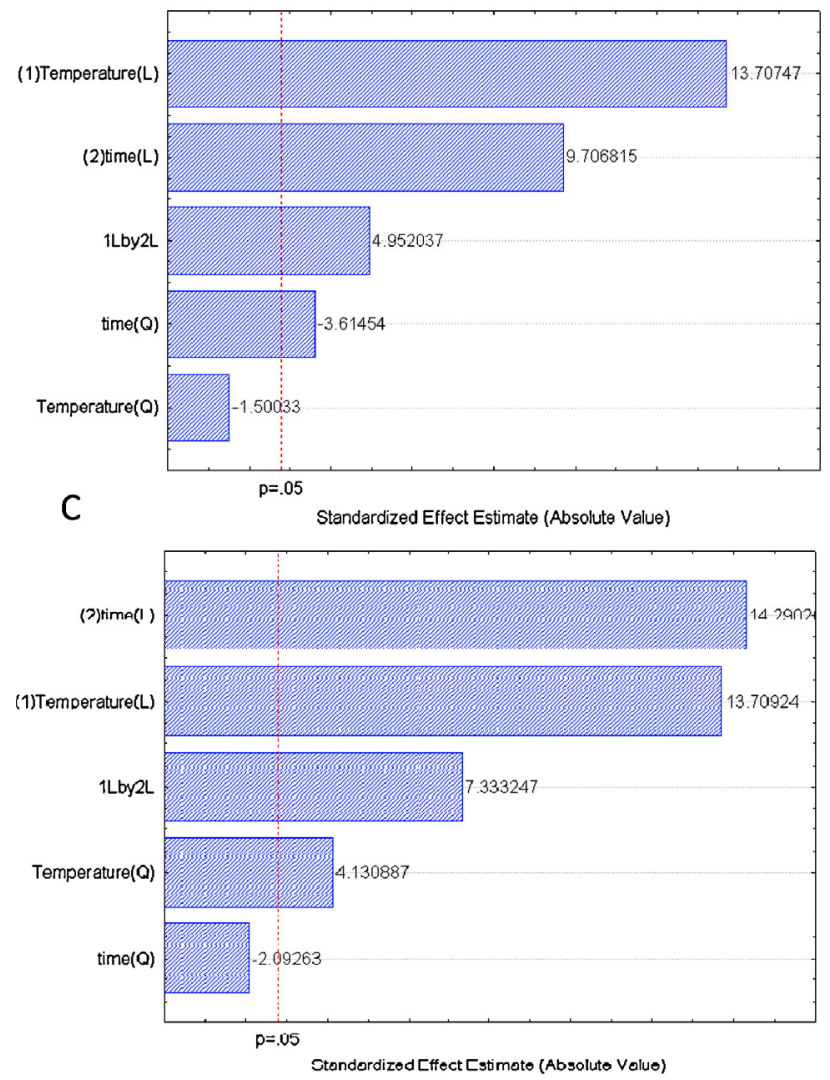
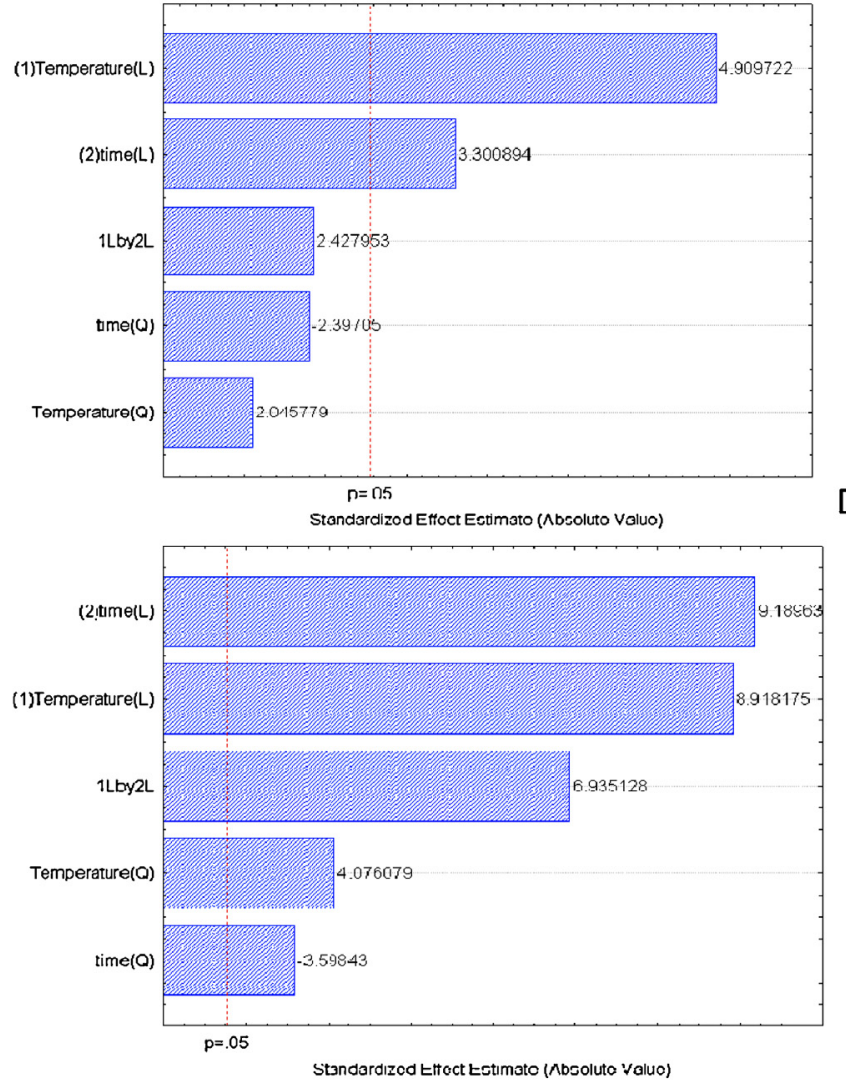

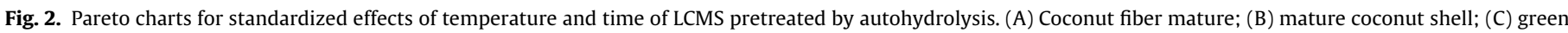
coconut shell; (D) cactus.

According to ANOVA results for cellulose variation in cactus pretreated by AP, the linear $X_{1}, X_{2}$, square $X_{1}{ }^{2}, X_{2}{ }^{2}$ and interaction $X_{1} X_{2}$ have a significant effect on cellulose variation responses and $p$-value with a significance level of $\alpha=0.05$. The effects can be visualized in Fig. 2D (standardized Pareto charts) and if observes the temperature, time, and temperature-time interaction are important with a confidence level of $95 \%$ on the cellulose variation and that the effect of temperature and time are positive, when increased from lower to higher values (Fig. 1D). The ANOVA results for cellulose variation in AP coconut fiber mature evidentiate that the linear $X_{1}, X_{2}$, square $X_{2}^{2}$ and interaction $X_{1} X_{2}$ have a significant effect on cellulose variation responses with $p$-value under a significance level of $\alpha=0.05$. The effects can be visualized in Fig. 2A (standardized Pareto charts)and it can be seen that temperature, time, and temperature-time interaction are important with a confidence level of $95 \%$ on the cellulose variation, and the effect of the temperature and time are positive, when increased from lower values to higher values (Fig. 1A). The ANOVA results for cellulose variation in mature coconut shell in AP show that the linear $X_{1}$ and $X_{2}$ have a significant effect on cellulose variation responses and $p$-value with a significance level of $\alpha=0.05$. The effects can be observed in Fig. 2B (standardized Pareto charts). As in previous situations, the variables temperature and time are important in the confidence level of $95 \%$ of the cellulose variation and the effect of temperature and time are positive, when increased from lower values to higher values (Fig. 1B). The ANOVA results for cellulose variation in mature coconut shell after AP demonstrate that the linear $X_{1}, X_{2}$, square $X_{1}^{2}$ and interaction $X_{1} X_{2}$ have a significant effect on cellulose variation responses and $p$-value with a significance level of $\alpha=0.05$. The effects can be observed in Fig. 2C (standardized Pareto charts) Similar conclusions to those observed for other materials were obtained on the effects of the temperature and time on cellulose variation in Fig. 1C. Furthermore, Fig. 3 shows predicted and observed values of the LCMs.

Table 4

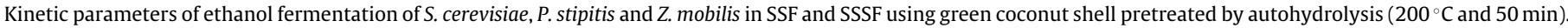

\begin{tabular}{|c|c|c|c|c|c|}
\hline Bioprocess & Microorganism & $Y_{\mathrm{P} / \mathrm{S}}$ & Ethanol yield (\%) & Ethanol production (g/L) & Ethanol productivity g/(L h) \\
\hline \multirow{3}{*}{ SSF } & S. cerevisiae & $0.44 \pm 0.00$ & $86.90 \pm 0.59$ & $7.44 \pm 0.17$ & $0.15 \pm 0.00^{*}$ \\
\hline & P. stipitis & $0.43 \pm 0.01$ & $84.19 \pm 2.60$ & $8.47 \pm 0.26$ & $0.18 \pm 0.01$ \\
\hline & Z. mobilis & $0.43 \pm 0.01$ & $85.26 \pm 1.45$ & $7.30 \pm 0.12$ & $0.15 \pm 0.00^{*}$ \\
\hline \multirow{3}{*}{ SSSF } & S. cerevisiae & $0.45 \pm 0.01$ & $90.09 \pm 1.60$ & $7.71 \pm 0.14$ & $0.16 \pm 0.00^{*}$ \\
\hline & P. stipitis & $0.44 \pm 0.01$ & $87.25 \pm 2.10$ & $8.78 \pm 0.21$ & $0.18 \pm 0.00$ \\
\hline & Z. mobilis & $0.45 \pm 0.00$ & $89.16 \pm 0.58$ & $7.63 \pm 0.05$ & $0.16 \pm 0.00^{*}$ \\
\hline
\end{tabular}

Note: * values are significant at a confidence level of $95 \%$.

$Y_{\mathrm{P} / \mathrm{S}}$ : ethanol yield (g ethanol/g sugar). 
A

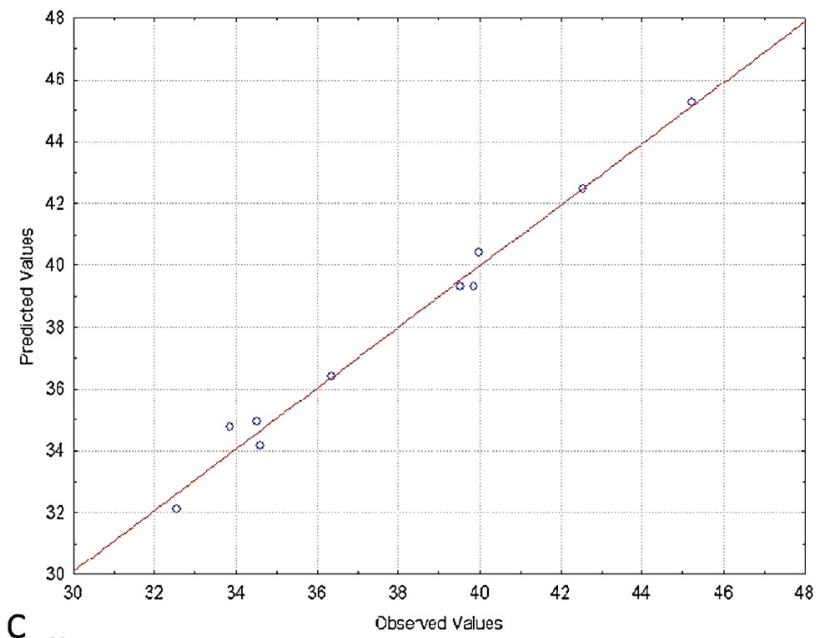

C

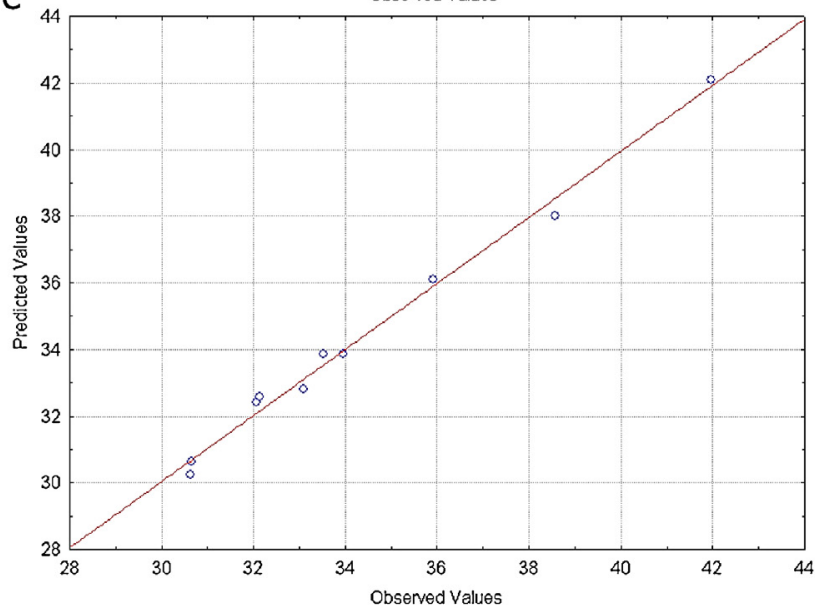

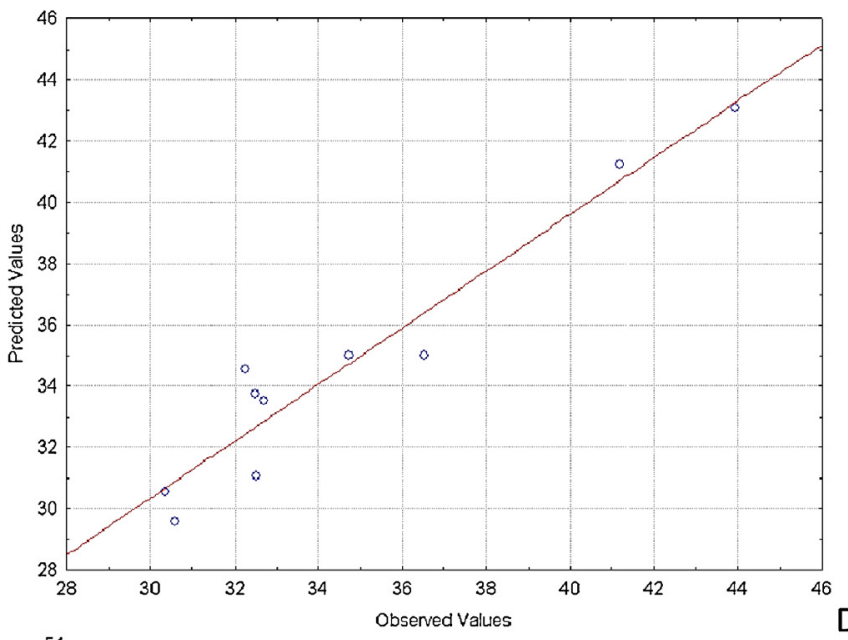

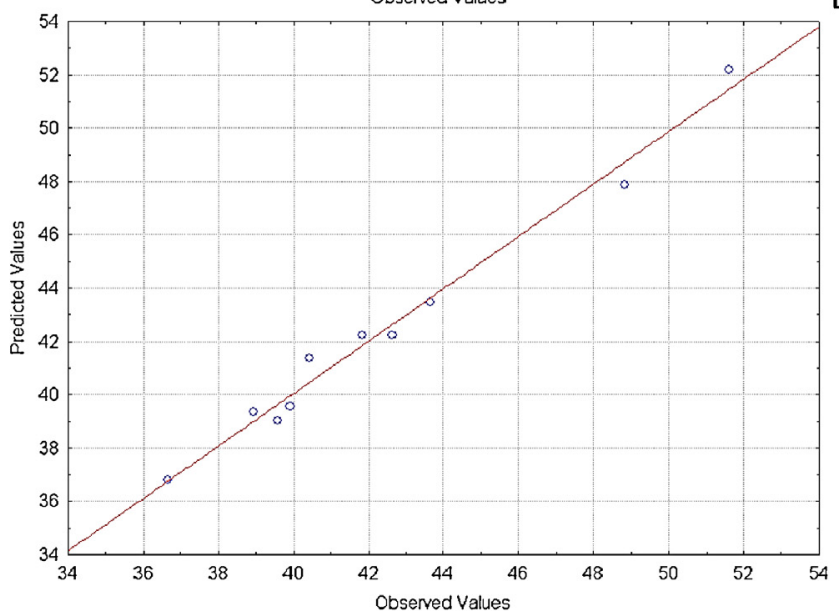

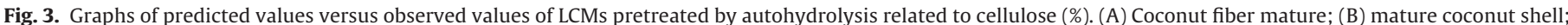
(C) green coconut shell; (D) cactus.

\subsection{Scanning electron microscopy}

The SEM images shown in Fig. 4 allowed to observe the effects caused by AP in the green coconut shell structure $\left(200^{\circ} \mathrm{C}\right.$ and $50 \mathrm{~min})$. The untreated sample shows the fibers highly ordered and surfaces intact (Fig. 4A). However, the LCM after AP (Fig. 4B) show modified structures, with increased surface area and porosity, fiber separation and disordered fibers. Structural features can give greater susceptibility to the pretreated LCM during the EH.

\subsection{Crystallinity and X-ray diffraction analysis}

The X-ray diffraction analysis and the crystallinity index determination were carried out in the untreated and AP green coconut shell aiming to analyze their crystalline structure.

Untreated green coconut shell crystallinity index was $29.31 \%$, while for AP pretreated material $\left(200^{\circ} \mathrm{C}\right.$ and $\left.50 \mathrm{~min}\right)$ the obtained value was $43.47 \%$ (Fig. 4C). The results showed an increase in the crystallinity index for the pretreated green coconut shell. When processing biomass by AP, Xu et al. (2013) observed the occurrence of increased crystallinity and specific surface area, mass loss and removal of the amorphous phase. Thompson et al. (1992) carried out AP in native mixed hardwood (with a crystallinity index of $71.6 \%$ ), the treatment resulting in crystallinity index values of $78.1 \%, 85.2 \%$ and $85.8 \%$, for increasing values $-240{ }^{\circ} \mathrm{C}, 260^{\circ} \mathrm{C}$ and $280^{\circ} \mathrm{C}$ - of the processing temperature. The results corroborate with the results obtained in this work, that green coconut shell submitted to AP also provides increased crystallinity index. According to Wei and Cheng (1985), the removal of amorphous cellulose and hemicellulose causes an increase in the crystallinity.

\subsection{Enzymatic hydrolysis}

The LCMs used in the EH stage were selected according to the cellulose content present in the solid phase after AP (Table 2 and Fig. 1A). Therefore, selected LCMs were those processed at a severity factor $R_{0}=4.64\left(200^{\circ} \mathrm{C}\right.$ and $\left.50 \mathrm{~min}\right)$; for these conditions, the composition of cellulose in cactus, coconut fiber mature, mature coconut shell and green coconut shell was $51.61 \%, 45.23 \%, 43.94 \%$ and $41.96 \%$, respectively.

Observed values for the conversion of cactus, coconut fiber mature, mature coconut shell and green coconut shell into glucose were $90.91 \%(0.43 \mathrm{~g} / \mathrm{g}), 84.10 \%(0.42 \mathrm{~g} / \mathrm{g}), 89.20 \%(0.43 \mathrm{~g} / \mathrm{g})$ and $92.52 \%(0.43 \mathrm{~g} / \mathrm{g})$ in $96 \mathrm{~h}$ of $\mathrm{EH}$ (Fig. $5 \mathrm{~A})$. The results evidence the accessibility of the pretreated LCMs in the EH and are according to the results shown by others authors, as Cybulska et al. (2010) that using AP $\left(210^{\circ} \mathrm{C}\right.$ for $\left.10 \mathrm{~min}\right)$, prairie cord grass obtained a glucose conversion of $97.96 \%$, after 72 h. Romaní et al. (2010) used Eucalyptus globulus in $\mathrm{AP}\left(200^{\circ} \mathrm{C}\right)$ and the obtained conversion in glucose by $\mathrm{EH}$ was $65 \%$, after $96 \mathrm{~h}$. Ruiz et al. (2012) used wheat straw in AP $\left(180^{\circ} \mathrm{C}\right.$ for $\left.30 \mathrm{~min}\right)$, obtaining an enzymatic conversion in glucose of $90.88 \%$, after $96 \mathrm{~h}$. Manzanares et al. (2011) studied olive tree 

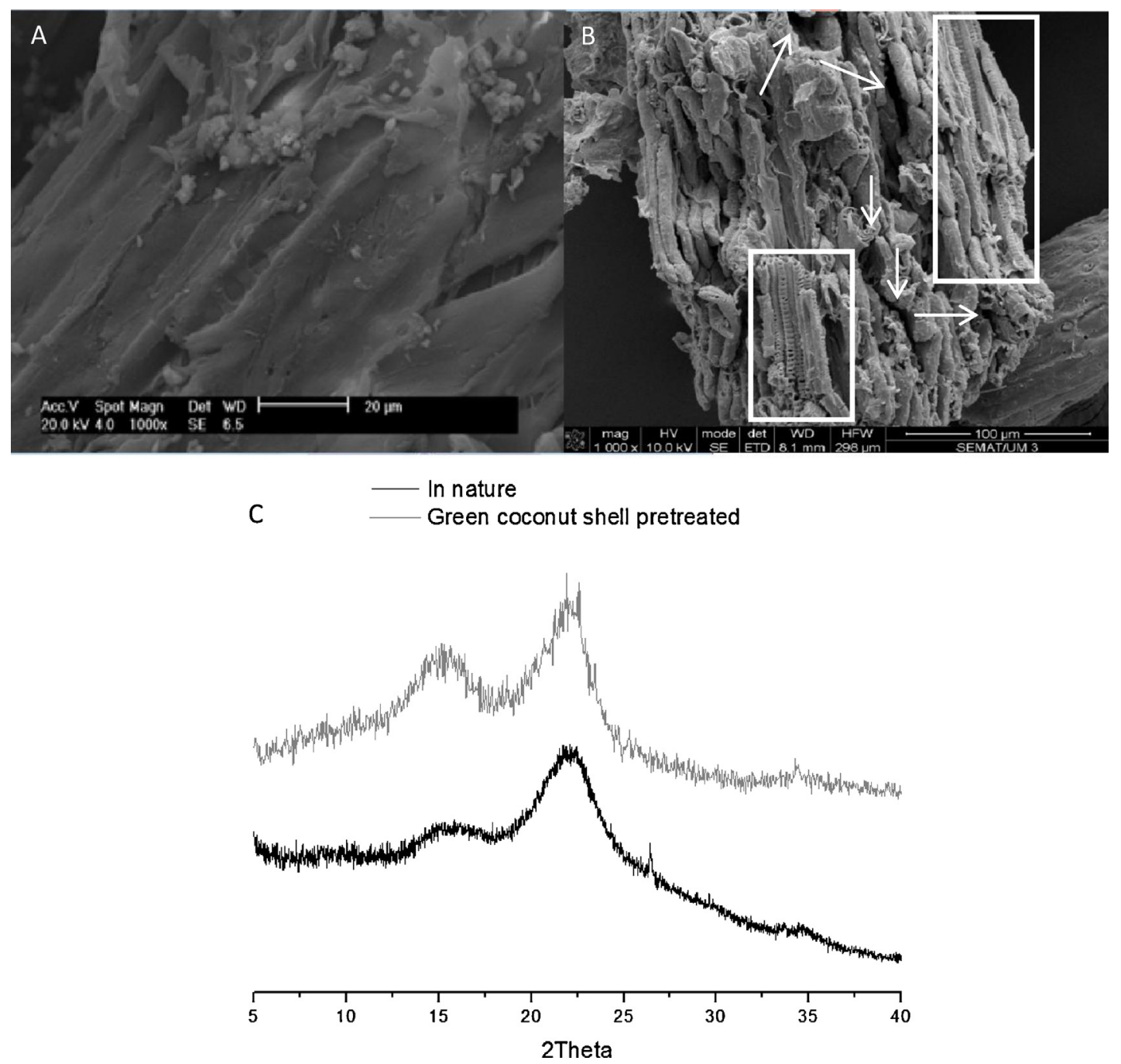

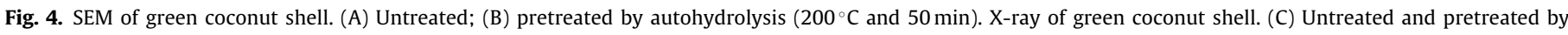
autohydrolysis $\left(200^{\circ} \mathrm{C}\right.$ and $\left.50 \mathrm{~min}\right)$. High porosity area, matrix separation and exposition fibers (white square).

pruning in $\mathrm{AP}\left(210^{\circ} \mathrm{C}\right.$ for $\left.10 \mathrm{~min}\right)$ with an enzymatic conversion into glucose of $65 \%$, in $72 \mathrm{~h}$. The results obtained in the EH were analyzed by ANOVA and showed in the level of confidence at $95 \%$ a significant differences, being the green coconut shell the LCM that allowed for the obtention of the highest yields of sugars.

Fig. 5B shows the maximum rate of initial hydrolysis $(d G / d t)$, corresponding to the $12 \mathrm{~h}$ initial (glucose concentration vs time). The maximum rate of initial hydrolysis for coconut fiber mature and mature coconut shell were $0.82 \mathrm{~g} /(\mathrm{Lh})$ and $0.91 \mathrm{~g} /(\mathrm{Lh})$, respectively. Green coconut shell and cactus had higher initial hydrolysis rates $-0.95 \mathrm{~g} /(\mathrm{Lh})$ and $1.03 \mathrm{~g} /(\mathrm{Lh})$, respectively. In comparison, Ruiz et al. (2012) reported the maximum rate of initial hydrolysis of $0.47 \mathrm{~g} /(\mathrm{Lh})$ using AP wheat straw and $30 \mathrm{FPU} / \mathrm{g}$ of cellulose. The results obtained in this work evidence the susceptibility of the LCMs to the enzymatic attack.

\subsection{Fermentative process for bioethanol production}

The SSF and SSSF were performed the S. cerevisiae PE2, P. stipitis Y7124, Z. mobilis B14023 and $4 \%(\mathrm{w} / \mathrm{v})$ of pretreated green coconut shell $\left(200^{\circ} \mathrm{C}\right.$ and $\left.50 \mathrm{~min}\right)$ as substrate, selected based on the $\mathrm{EH}$ yield (Fig. 5). The efficiency of the SSF and SSSF was examined by two indicators: yield and volumetric productivity of ethanol (Shen and Agblevor, 2010).

\subsubsection{Simultaneous saccharification and fermentation and} semi-simultaneous saccharification and fermentation

The SSF ethanol production results by $P$. stipitis, $Z$. mobilis and S. cerevisiae are shown in Fig. 6A-C, respectively, obtaining results indicate that glucose from $\mathrm{EH}$ could be fermented to ethanol by the microorganisms. The glucose presented the standard kinetic profiles with a rapid consumption in the first $24 \mathrm{~h}$. Final ethanol concentration and ethanol yield in SSF by P. stipitis, Z. mobilis and $S$. cerevisiae were $8.47 \mathrm{~g} / \mathrm{L}$ and $0.43 \mathrm{~g} / \mathrm{g}(84.19 \%), 7.30 \mathrm{~g} / \mathrm{L}$ and $0.43 \mathrm{~g} / \mathrm{g}$ (85.26\%), $7.44 \mathrm{~g} / \mathrm{L}$ and $0.44 \mathrm{~g} / \mathrm{g}(86.90 \%)$, being the SSF process completed after $48 \mathrm{~h}$, respectively (Fig. 6 and Table 4). For P. stipitis the volumetric productivity of ethanol was $0.18 \mathrm{~g} /(\mathrm{Lh})$, while for $Z$. mobilis and $S$. cerevisiae the obtained values were $0.15 \mathrm{~g} /(\mathrm{Lh})$, for both (Table 4). The three microorganisms proved to be suitable for fermenting sugars to ethanol by SSF. The results reported in this work are in conformity with the results presented by Romaní et al. (2010) for ethanol production by SSF of AP E. globulus $(10 \% \mathrm{w} / \mathrm{v}$ of pretreated solids) using $S$. cerevisiae, that obtained production, conversion and productivity of ethanol values of $15.1 \mathrm{~g} / \mathrm{L}, 86.4 \%$ and $0.21 \mathrm{~g} /(\mathrm{L} \mathrm{h})$, respectively. Additionally, Romaní et al. (2012) carried out ethanol production by SSF of AP E. globulus $(10 \% \mathrm{w} / \mathrm{v}$ of pretreated solids) by $S$. cerevisiae, reporting production, conversion and productivity of ethanol values of $67.4 \mathrm{~g} / \mathrm{L}, 91.1 \%$ and $0.93 \mathrm{~g} /(\mathrm{L} \mathrm{h})$, respectively. 


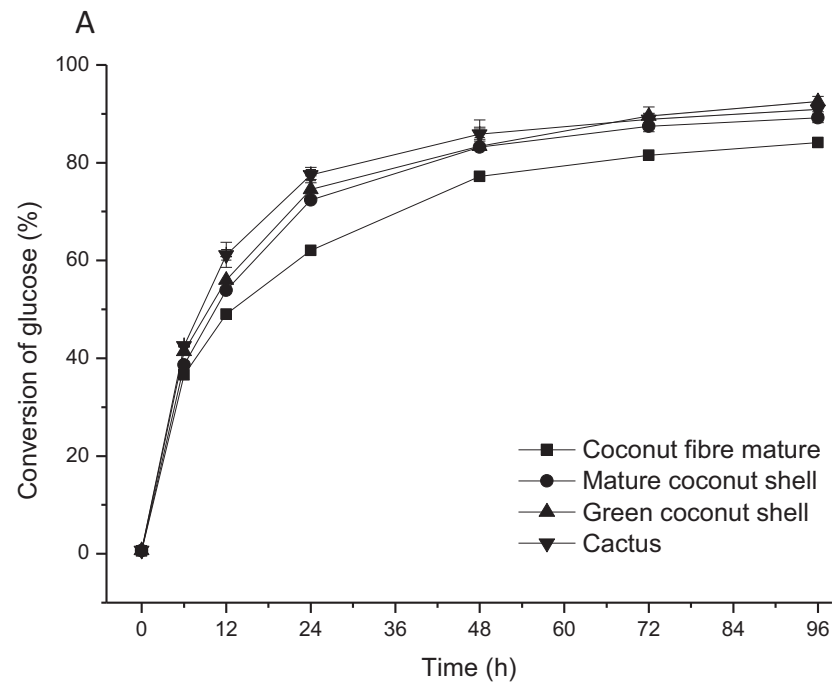

B

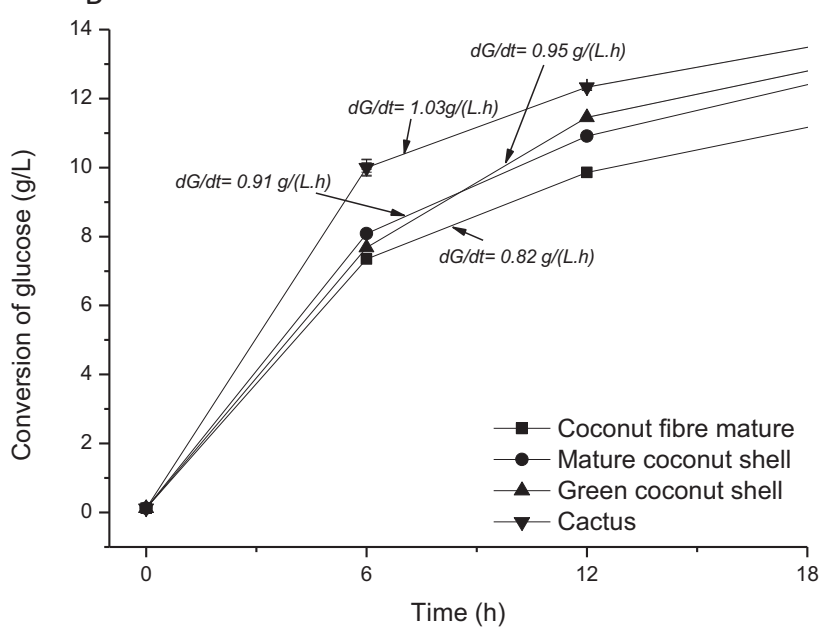

Fig. 5. Enzymatic hydrolysis of LCMs pretreated by autohydrolysis $\left(200^{\circ} \mathrm{C}\right.$ and $50 \mathrm{~min}$ ). (A) Conversion yield (\%); (B) initial hydrolysis rate at $12 \mathrm{~h}$. Enzyme loading of $30 \mathrm{FPU}, 75 \mathrm{CBU}$ and $130 \mathrm{IU}$ per gram of pretreated solid.

In the experiments, SSSF had similar results concerning glucose availability during the initial phase of $12 \mathrm{~h}$, with a gradual reduction of glucose with time (Fig. 6A-C). The values obtained of the ethanol concentration and yield with the SSSF strategy using P. stipitis, $Z$. mobilis and $S$. cerevisiae are presented in Fig. $6 \mathrm{~A}-\mathrm{C}$ and Table 4, being $8.78 \mathrm{~g} / \mathrm{L}$ and $0.44 \mathrm{~g} / \mathrm{g}$ (87.25\%), $7.63 \mathrm{~g} / \mathrm{L}$ and $0.45 \mathrm{~g} / \mathrm{g}$ (89.16\%), $7.71 \mathrm{~g} / \mathrm{L}$ and $0.45 \mathrm{~g} / \mathrm{g}(90.09 \%)$, respectively for each microbial strain after $48 \mathrm{~h}$. For $P$. stipitis the volumetric productivity of ethanol was $0.18 \mathrm{~g} /(\mathrm{L} \mathrm{h})$ in $36 \mathrm{~h}$, while for $Z$. mobilis and S. cerevisiae the achieved values were $0.16 \mathrm{~g} /(\mathrm{Lh})$ and $0.21 \mathrm{~g} /(\mathrm{Lh})$, respectively (Table 4). The results achieved in this work corroborated with the results reported by Manzanares et al. (2011) that carried out the SSSF, being $24 \mathrm{~h}$ of presaccharification and $72 \mathrm{~h}$ of SSF, using residue pruning olive as raw material ( $17 \% \mathrm{w} / \mathrm{v}$ of pretreated solids). The application of SSSF resulted in the ethanol production at a concentration of $50 \%$ of the theoretical value. Mesa et al. (2011) used pretreated sugarcane bagasse, producing $15.7 \mathrm{~g}$ ethanol $/ 100 \mathrm{~g}$ of raw material $(68.4 \%$ of ethanol).

The ethanol production by the P. stipitis, Z. mobilis and $S$. cerevisiae utilizing the fermentative strategies SSF and SSSF was assessed statistically using ANOVA and $t$-test, both with $95 \%$ confidence level. The SSF using microorganisms demonstrated no significant differences in the ethanol production, when assessed by the ANOVA. The fermentation performance of the microorganisms
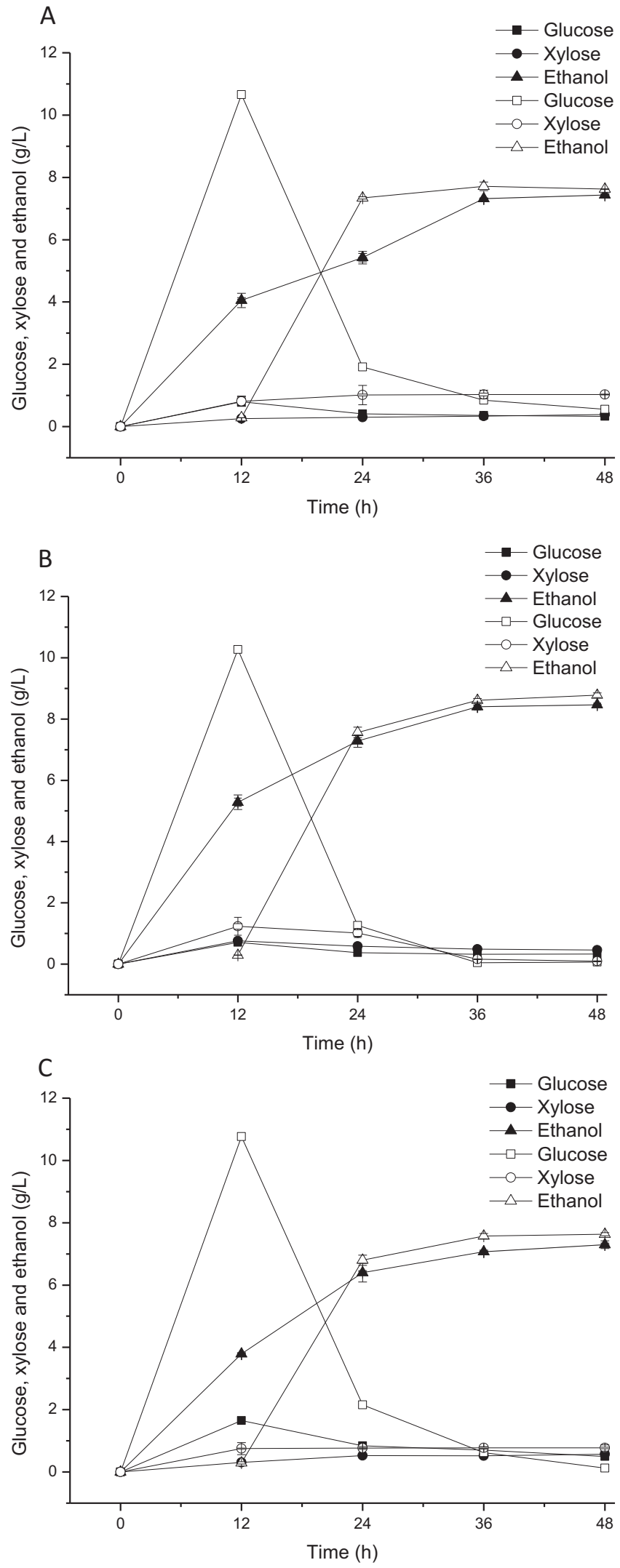

Fig. 6. Fermentation in SSF and SSSF of green coconut shell pretreated by autohydrolysis $\left(200^{\circ} \mathrm{C}\right.$ and $\left.50 \mathrm{~min}\right)$. (A) S. cerevisiae; (B) P. stipitis; (C) Z. mobilis. The SSF was represented by the black icon and SSSF was represented by the white icon. 
using SSSF showed a similar result the SSF. However, the comparison of the achieved results by the $Z$. mobilis utilizing the SSSF and SSF showed a significant difference, when assessed by the $t$-test. A similar result was also shown by $S$. cerevisiae.

The achieved results in the production and the yield of ethanol in SSF are minors, when compared the SSSF (Table 4). De Souza et al. (2012) reported that in relation to SHF and SSF the presaccharification has a possible positive effect, increasing the yield and volumetric productivity of ethanol. Öhgren et al. (2007) showed the influences on the global ethanol yield of pretreated corn stover utilizing the presaccharification before of the SSF. They concluded that the fast decrease in the viscosity provided by the presaccharification can have a relevant impact on the unit operations before SSF. Santos et al. (2010) utilized the SSSF and SSF processes obtained the higher production and productivity of ethanol with the use of the pre-saccharification before to SSF. Mesa et al. (2011) also evaluated the application of SHF, SSF and SSSF for ethanol production using 1 ton of sugarcane bagasse, obtaining 192, 172 and $198 \mathrm{~L}$ of ethanol, respectively. These results demonstrate the importance of performing the presaccharification step before the fermentative process and corroborate the results achieved in this work.

\section{Conclusion}

Cactus, mature coconut shell, coconut fiber mature and green coconut shell submitted to autohydrolysis pretreatment were shown to be promising raw materials for application in the context of biorefinery, as from the elevated versatility and practicality in the fractionation of the LCMs (a reduction in the hemicellulose content, and increase of the cellulose and lignin) with high conversions into glucose by $\mathrm{EH}$. As the best results on $\mathrm{EH}$ were obtained from green coconut shell (92.52\%), this LCM was selected for ethanol production being shown that the best results on ethanol yield (90.09\%) and ethanol productivity $(0.21 \mathrm{~g} /(\mathrm{Lh}))$ from green coconut shell were obtained by $S$. cerevisiae using SSSF. Therefore, an efficient process was developed for the bioethanol production from green coconut shell.

\section{Acknowledgments}

The authors gratefully acknowledge by the financial support of the Brazilian research funding agencies CNPq (Proc:470356/20111) and CAPES (Proc:BEX5951/11-9).

\section{References}

Ballesteros, I., Oliva, J.M., Negro, M.J., Manzanares, P., Ballesteros, M., 2002. Enzymatic hydrolysis of steam exploded herbaceous agricultural waste (Brassica carinata) at different particle sizes. Process. Biochem. 38, 187-192.

Bastos, V.D., 2007. Ethanol, alcoholchemistry and biorefineries. BNDES Set. Rio de Janeiro 25, 5-38

Bobleter, O., Niesner, R., Röhr, M., 1976. The hydrothermal degradation of cellulosic matter to sugars and their fermentative conversion to protein. J. Appl. Polym. Sci. 20, 2083-2093.

Cara, C., Romero, I., Oliva, J.M., Sáez, F., Castro, E., 2007. Liquid hot water pretreatment of olive tree pruning residues. Appl. Biochem. Biotechnol. 136-140, 379-394.

Cybulska, I., Lei, H., Julson, J., 2010. Hydrothermal pretreatment and enzymatic hydrolysis of prairie cord grass. Energy Fuel 24, 718-727.

De Souza, C.J.A., Costa, D.A., Rodrigues, M.Q.R.B., dos Santos, A.F., Lopes, M.R., Abrantes, A.B.P., Costa, P.S., Silveira, W.B., Passos, F.M.L., Fietto, L.G., 2012. The influence of presaccharification, fermentation temperature and yeast strain on ethanol production from sugarcane bagasse. Bioresour. Technol. 109, 63-69.

Dowe, N., McMillan, J., 2001. SSF experimental protocols-lignocellulosic biomass hydrolysis and fermentation. In: NERL Analytical Procedure. National Renewable Energy Laboratory, Golden, $\mathrm{CO}$

FAO, 2012. World Production, Available in http://www.faostat.org.br (accessed 10.02.13).
Garrote, G., Domínguez, H., Parajó, J.C., 2002. Autohydrolysis of corncob: study of non-isothermal operation for xylooligosaccharides production. J. Food Eng. 52, 211-218.

Garrote, G., Cruz, J.M., Domínguez, H., Parajó, J.C., 2003. Valorisation of waste fractions from autohydrolysis of selected lignocellulosic materials. J. Chem. Technol. Biotechnol. 78, 392-398.

Ghose, T.K., 1987. Measurement of cellulose activities (recommendation of commission on biotechnology IUPAC). Pure Appl. Chem. 59, 257-268.

Gonçalves, F.A., Ruiz, H.A., Nogueira, C.C., dos Santos, E.S., Teixeira, J.A., de Macedo G.R., 2014. Comparison of delignified coconuts waste and cactus for fuel-ethanol production by the simultaneous and semi-simultaneous saccharification and fermentation strategies. Fuel 131, 66-76.

Gullón, B., Yáñez, R., Alonso, J.L., Parajó, J.C., 2010. Production of oligosaccharides and sugars from rye straw: a kinetic approach. Bioresour. Technol. 101, 6676-6684.

IBGE - Instituto Brasileiro de Geografia e Estatística, 2012. Levantamento Sistemático da produção Agrícola: pesquisa mensal de previsão e acompanhamento das safras agrícolas no ano civil. Fundação Instituto Brasileiro de Geografia e Estatística, Rio de Janeiro.

Luo, L., van der Voet, E., Huppes, G., 2010. Biorefining of lignocellulosic feedstock technical, economic and environmental considerations. Bioresour. Technol. 101 5023-5032.

Mandels, M., Andreotti, R., Roche, C., 1976. Measurement of saccharifying cellulase. Biotechnol. Bioeng. Symp. 6, 21-23.

Manzanares, P., Negro, M.J., Oliva, J.M., Sáez, F., Ballesteros, I., Ballesteros, M., 2011. Different process configurations for bioethanol production from pretreated olive pruning biomass. J. Chem. Technol. Biotechnol. 86, 881-887.

Mesa, L., González, E., Romero, I., Ruiz, E., Cara, C., Castro, E., 2011. Comparison of process configurations for ethanol production from two-step pretreated sugarcane bagasse. Chem. Eng. J. 175, 185-191.

Moure, A., Gullón, P., Domínguez, H., Parajó, J.C., 2006. Advances in the manufacture, purification and applications of xylo-oligosaccharides as food additives and nutraceuticals. Process. Biochem. 41, 1913-1923.

NREL, 2012. National Renewable Energy Laboratory, Available in http://www.nrel gov/biomass/biorefinery.html (accessed 11.09.12).

Öhgren, K., Vehmaanperä, J., Siika-Aho, M., Galbe, M., Viikari, L., Zacchi, G., 2007. High temperature enzymatic prehydrolysis prior to simultaneous saccharification and fermentation of steam pretreated corn stover for ethanol production. Enzyme Microbial Technol. 40, 607-613.

Overend, R.P., Chornet, E., 1987. Fractionation of lignocellulosic by steam-aqueous pretreatments. Philos. Trand. R. Soc. Lond. A 321, 523-536.

Romaní, A., Garrote, G., Alonso, J.L., Parajó, J.C., 2010. Bioethanol production from hydrothermal pretreated Eucalyptus globulus wood. Bioresour. Technol. 101, 8702-8706.

Romaní, A., Garrote, G., López, F., Parajó, J.C., 2011. Eucalyptus globulus wood fractionation by autohydrolysis and organosolv delignification. Bioresour. Technol. 102, 5896-5904.

Romaní, A., Garrote, G., Parajó, J.C., 2012. Bioethanol production from autohydrolyzed Eucalyptus globulus by simultaneous saccharification and fermentation operating at high solids loading. Fuel 94, 305-312.

Ruiz, H.A., Rodríguez-Jasso, R.M., Fernandes, B.D., Vicente, A.A., Teixeira, J.A., 2013. Hydrothermal processing, as an alternative for upgrading agriculture residues and marine biomass according to the biorefinery concept: a review. Renew. Sust. Energy Rev. 21, 35-51.

Ruiz, H.A., Vicente, A.A., Teixeira, J.A., 2012. Kinetic modeling of enzymatic saccharification using wheat straw pretreated under autohydrolysis and organosolv process. Ind. Crop Prod. 36, 100-107.

Sakaki, T., Shibata, M., Sumi, T., Yasuda, S., 2002. Saccharification of cellulose using a hot-compressed water-flow reactor. Ind. Eng. Chem. Res. 41, 661-665.

Santos, J.R.A., Souto-Maior, A.M., Gouveia, E.R., Martin, C., 2010. Comparação entre processos em SHF e em SSF de bagaço de cana-de-açúcar para a produção de etanol por Saccharomyces cerevisiae. Quim. Nova 33, 904-908.

Segal, L., Creely, J., Martin, A., Conrad, J.C., 1959. An empirical method for estimating the degree of crystallinity of native cellulose using the X-ray diffractometer. Text. Res. J. 29, 786-794.

Shen, J., Agblevor, F.A., 2010. Modeling semi-simultaneous saccharification and fermentation of ethanol production from cellulose. Biomass Bioenergy 34 1098-1107.

Shen, J., Agblevor, F.A., 2011. Ethanol production of semi-simultaneous saccharification and fermentation from mixture of cotton gin waste and recycled paper sludge. Bioprocess Biosyst. Eng. 34, 33-43.

Sluiter, A., Hames, B., Hyman, D., Payne, C., Ruiz, R., Scarlata, C., Sluiter, J., Templeton, D., Wolfe, J., 2008. Determination of Total Solids in Biomass and Total Dissolved Solids in Liquid Process Samples. National Renewable Energy Laboratory, Golden, CO.

Thompson, D.N., Chen, H.C., Grethlein, H.E., 1992. Comparison of pretreatment methods on the basis of available surface area. Bioresour. Technol. 39, 155-163.

Uihlein, A., Schebek, L., 2009. Environmental impacts of a lignocellulose feedstock biorefinery system: an assessment. Biomass Bioenergy 33, 793-802.

Wei, C., Cheng, C., 1985. Effect of hydrogen peroxide pretreatment on the structural features and the enzymatic hydrolysis of rice straw. Biotechnol. Bioeng. 27, 1418-1426.

Xu, F., Shi, Y.C., Wang, D., 2013. X-ray scattering studies of lignocellulosic biomass: a review. Carbohyd. Polym. 94, 904-917. 